\title{
WestVirginiaUniversity
}

THE RESEARCH REPOSITORY @ WVU

West Virginia Agricultural and Forestry Experiment

Davis College of Agriculture, Natural Resources

Station Bulletins

And Design

$1-1-1985$

\section{Interregional competition in the U.S. broiler industry}

Hui-Yuan Chen Wu

Robert L. Jack

Follow this and additional works at: https://researchrepository.wvu.edu/

wv_agricultural_and_forestry_experiment_station_bulletins

\section{Digital Commons Citation}

Wu, Hui-Yuan Chen and Jack, Robert L., "Interregional competition in the U.S. broiler industry" (1985). West Virginia Agricultural and Forestry Experiment Station Bulletins. 692.

https://researchrepository.wvu.edu/wv_agricultural_and_forestry_experiment_station_bulletins/586

This Bulletin is brought to you for free and open access by the Davis College of Agriculture, Natural Resources And Design at The Research Repository @ WVU. It has been accepted for inclusion in West Virginia Agricultural and Forestry Experiment Station Bulletins by an authorized administrator of

The Research Repository @ WVU. For more information, please contact ian.harmon@mail.wvu.edu. 
Interregional Competition in the U.S. Broiler Industry

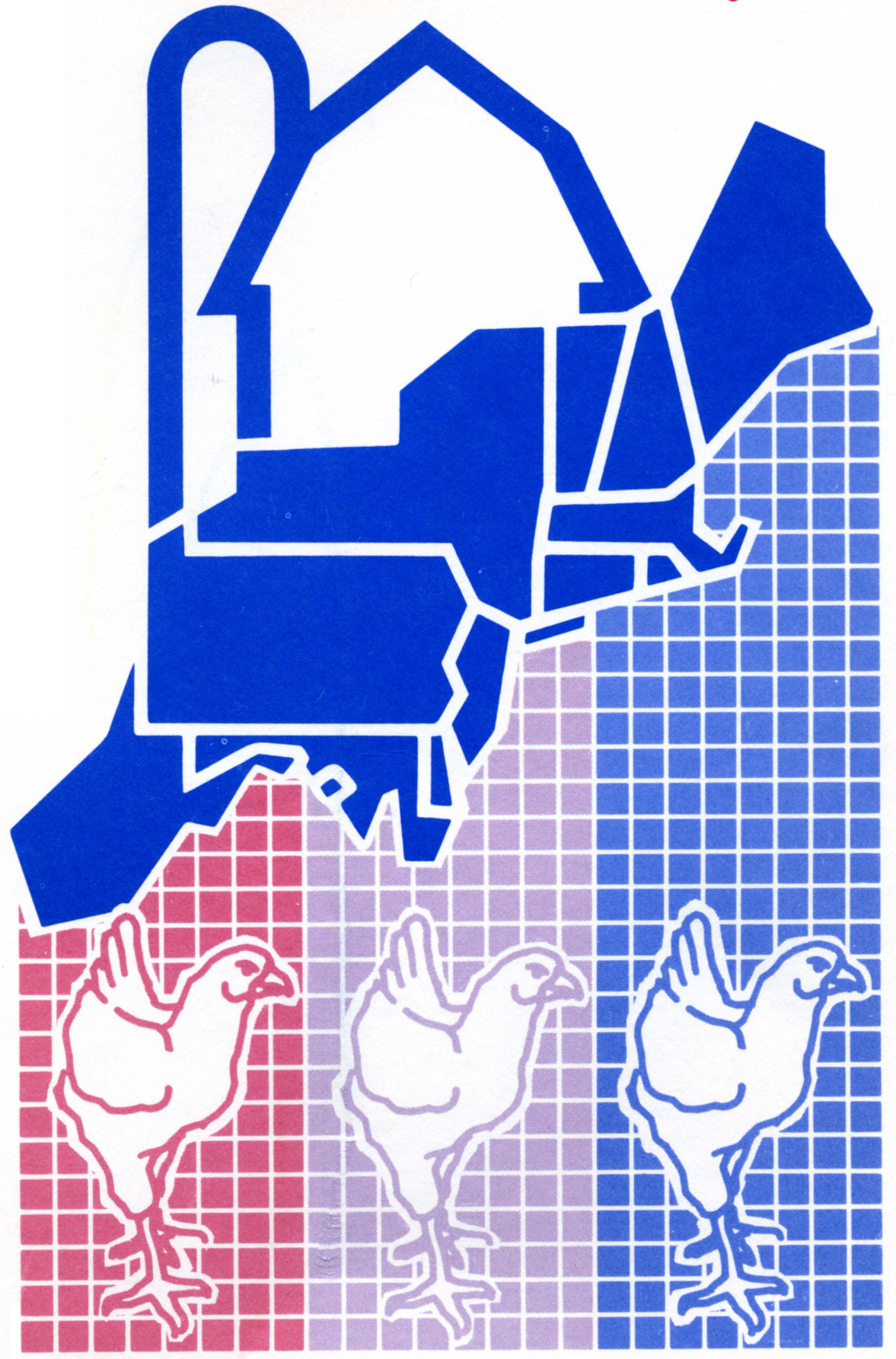

BULLETIN 692

W February 1985

630.72 Agricultural and Forestry Experiment Station w5 2b West Virginia University 
[Blank Page in Original Bulletin] 
Interregional Competition in the U.S. Broiler Industry

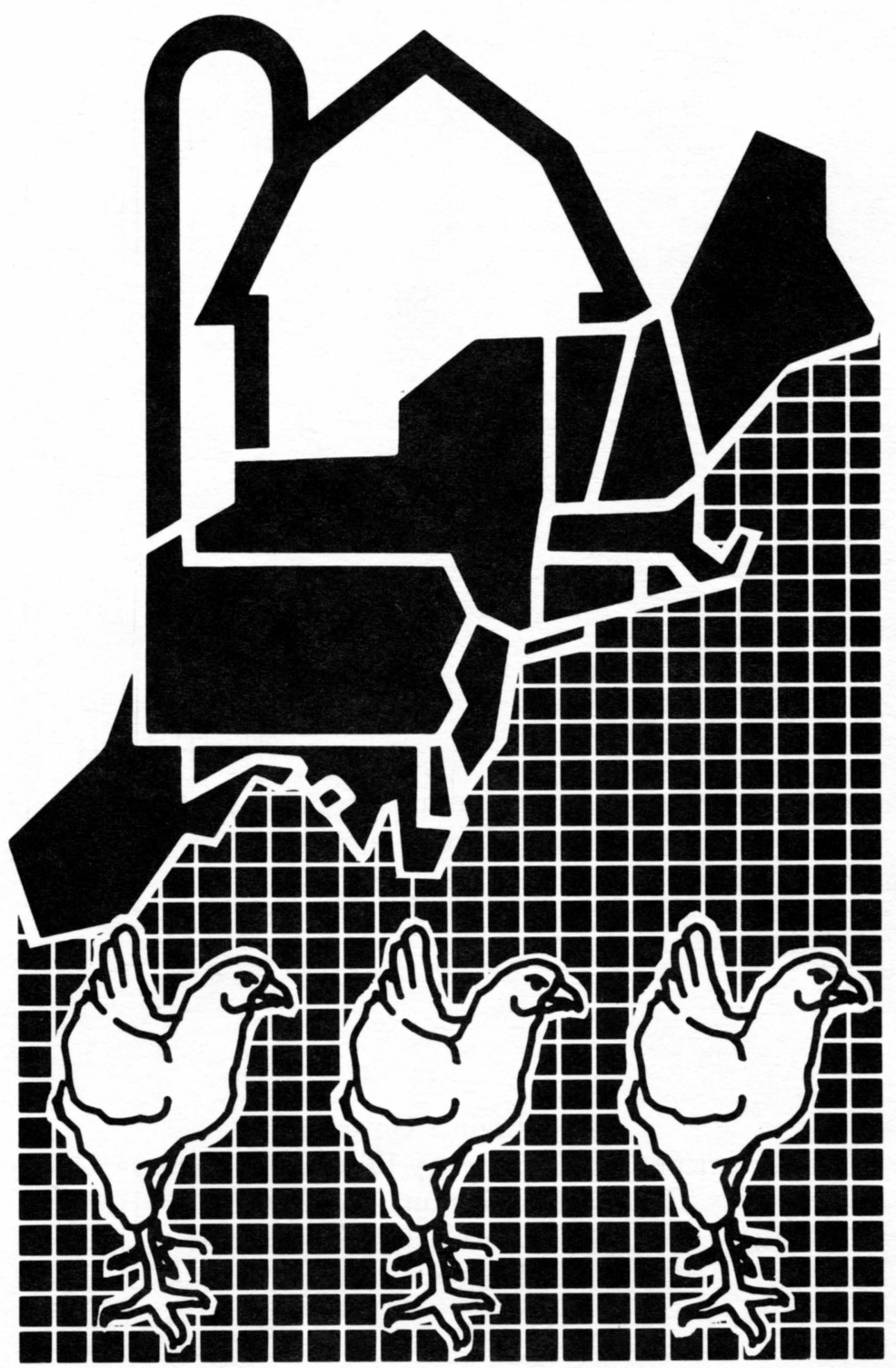




\section{Authors}

Hui-Yuan Wu was a graduate research assistant in agricultural economics and Robert L. Jack is professor of agricultural economics, agricultural economist, and acting chairman of the Division of Resource Management.

Published as a contribution to the Northeast Regional Marketing Project (NE134). The West Virginia research for this publication was supported by state and regional research funds.

West Virginia University

Agricultural and Forestry Experiment Station

College of Agriculture and Forestry

Robert H. Maxwell, Interim Director

Morgantown 


\section{Contents}

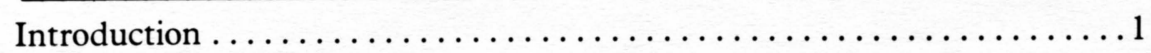

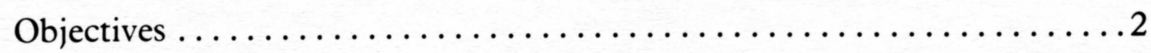

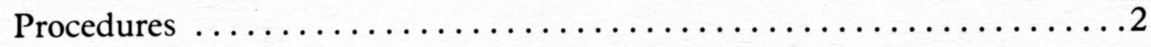

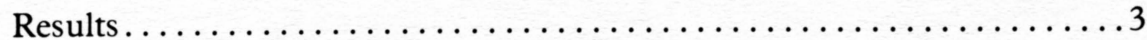

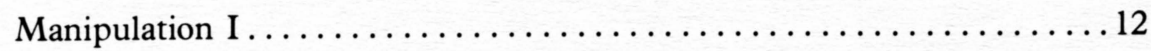

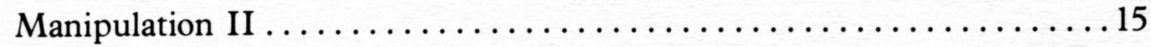

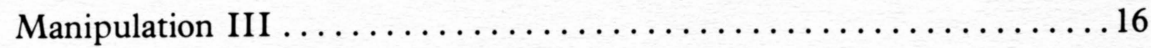

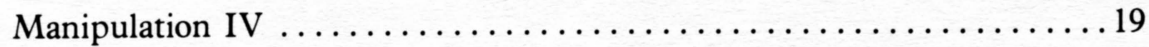

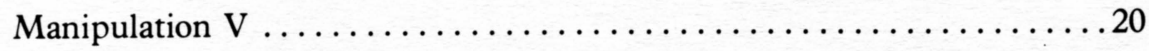

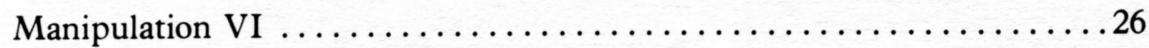

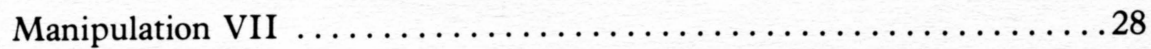

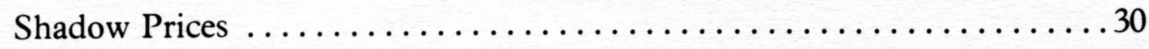

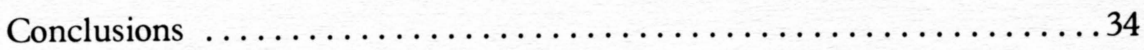

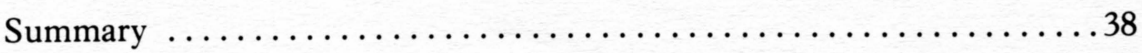


[Blank Page in Original Bulletin] 


\title{
Interregional Competition in the U.S. Broiler Industry
}

\author{
Hui-Yuan Wu and Robert L. Jack
}

\section{Introduction}

The broiler industry has experienced dramatic growth in the United States. ${ }^{1}$ In 1955 , commercial broiler production was 3.3 billion pounds liveweight. The average farm price was 25.2 cents per pound and gross farm income from broilers totaled $\$ 0.8$ billion. By 1980 , the production was 15.5 billion pounds liveweight, with an average farm price of 27.7 cents per pound and gross farm income from broilers had increased to $\$ 4.3$ billion. The industry's phenomenal growth is the result of new production and marketing technologies, significant changes in industry economic structure, concentration and management practices, and the impact of government policies and programs on agriculture.

Historically, broiler production has been concentrated in small geographical areas. However, the industry experienced geographical shifts during the past twenty-five years. The Delmarva broiler industry has long been a leader in the production and marketing of broilers. The area produced more broilers than any other area until 1957 when Georgia took the lead in production. Then in 1971, Arkansas took the production lead, a situation that has lasted to the present. More generally, the Northeastern broiler industry has lost market shares to the Southeastern and Southcentral production areas.

The twelve leading states in broiler production in 1980, by rank, were Arkansas, Georgia, Alabama, North Carolina, Mississippi, Maryland, Texas, California, Delaware, Virginia, Pennsylvania, and Maine. There has been little change in the share of total production accounted for by these twelve leading states in recent years. Rank among states also has been somewhat constant. These twelve states accounted for an average of 88.2 percent of total U.S. production during the period of 1971 to 1980 . Of these states, nine are located in the South Atlantic or South Central region, two are in the North Atlantic, and one in the West Coast region.

Agriculture in general and the poultry industry in particular are subject to a high level of interregional competition. Broiler production in the Southeastern and Southcentral production areas has been increasing rapidly since 1957, while the Northeastern region has changed from a surplus to a deficit position. It is appropriate to ask why this has happened. It is believed that decreasing farm price for broilers and higher transportation costs of feed placed the Northeastern producers at a comparative disadvantage relative to their 
southern competitors. Also, a reduction of costs in the South, via lower grain freight rates, had important competitive effects upon the Northeastern region.

These interregional relationships in the broiler markets need further discussion. A better understanding of the intensity of spatial competition within the broiler industry would be helpful. Also, the answers to the following questions should be found. What are the possible impacts of alternative market conditions on the industry; such as, an increase in the transportation cost for the final product and/or regional feed price increases? What are the optimal production levels and transportation flow patterns for the 1990 broiler industry, on the assumption that regional consumption levels are known?

\section{Objectives}

The general objective of this study was to develop an interregional competition model to determine efficient allocation of broiler production over the United States, ${ }^{2}$ and with that model to quantitatively estimate industry reaction to various changes which could occur. Thus, the answers to the aforementioned questions would be obtained.

\section{Procedures}

A spatially competitive LP model was developed to obtain the least-cost shipping pattern of broilers in the United States. Adjusted aggregate regional consumption, truck rates between all possible combinations of production and consumption regions, quantity supplied, and production and processing plant costs were used to construct the Basic Model. This was solved by using the IBM LP routine to determine the distribution patterns that could minimize total production and transportation costs. Thereafter, seven manipulations were developed to examine the solutions involving variations in production capacity, transportation rates, production and processing plant costs, and projection of consumption to 1990 .

Production and consumption of broilers take place in many areas of the country. To simplify the problem, only the major areas were selected for study. The Basic Model and all manipulations used 10 production regions and 22 consumption regions; except Manipulation IV, which used 7 production regions and 16 consumption regions.

The twelve leading producing states were divided into ten major production regions on the basis of location. ${ }^{3}$ Each state is a region, except that Maryland, Delaware, and Virginia were combined into one, because broiler production in these states is concentrated in the Delmarva Peninsula of Maryland, Delaware, 
and Virginia. Each production region is represented by a city located in or near the major broiler production area within the region (Table 1, Figure 1). Twenty-two consumption regions were defined in the analyses. Each consumption region is represented by one city, chosen on the basis of population density and geographical centrality (Table 2, Figure 2).

In constructing the model an attempt was made to bring together current information which would reflect actual conditions existing in the broiler industry. The model should identify realistic industry adjustments to future economic shocks. The number of reactions to economic shocks examined in this study is just a sample of the model's capabilities. There are numerous combinations of changes which could be analyzed with the model. However, the economic shocks examined in this study are those considered to be important to the industry today. The solutions would hopefully help those in the industry make better production and marketing decisions in the future.

\section{Results}

In the Basic Model and first four manipulations, regional consumption of broilers was derived by multiplying 1980 regional population estimates by overall U.S. per capita consumption for 1980 (46.9 pounds per capita). The production capacity used in the model was the amount of 1980 production reported for each production region. The production data were adjusted to a ready-to-cook (RTC) basis.

In the Basic Model, broilers were produced only in ten designated production regions which accounted for 87.5 percent of U.S. total production in 1980 (Table 1). However, consumption of broilers was considered nationwide. ${ }^{4}$ Hence, production was less than consumption in the Basic Model. Therefore, the consumption in regions more distant from the major production regions was not satisfied. In this case, consumption in regions 21 (Oregon-Washington) and 22 (California) was not satisfied.

Figure 3 shows the interregional movements which minimize the 1980 total production and transportation costs in the Basic Model. The numbers on the arrows are the amount of broilers in million pounds (RTC basis) shipped to each consumption region. Underscored numbers indicate production consumed within the production region. Minus figures in parentheses indicate a shortage of supply. The principal direction of movements in this solution is from south to north. These model results coincide with our present knowledge of the allocative pattern of the U.S. broiler industry. Most production regions

\footnotetext{
${ }^{3}$ Except Manipulation IV.

${ }^{4}$ Excludes Alaska and Hawaii.
} 
fulfill their own consumption before shipping surplus to other consumption regions. The 1980 aggregate cost of U.S. broiler production and transportation in the Basic Model was $\$ 5,802.5$ million.

The movement of broilers within and between regions is a fundamental part of the marketing system. Several studies have measured the actual geographical movements of broilers. However, such studies do not provide continuing measurements. Recent estimates are not available. Therefore, the interregional movement of 1975 was selected for comparison with the solution of the Basic Model, which is for 1980. Also, both production and consumption regions of the Basic Model are grouped according to the same criterion used in the 1975 situation for the comparison (Tables 3 and 4).

Figures 4 and 5 show actual interregional shipments of broilers in 1975 and least-cost shipments for the Basic Model, respectively. The flow patterns are very similar in the two situations. This can be interpreted to mean that the broiler industry has achieved efficiency in resource allocation under present market conditions.

\section{Table 1}

U.S. Broiler Production by Production Region, 1980

\begin{tabular}{|c|c|c|}
\hline Production Region & Production $(\mathrm{RTC})^{\star}$ & $\begin{array}{l}\text { Share of Total } \\
\text { U.S. Production }\end{array}$ \\
\hline & (million pounds) & (percentage) \\
\hline Arkansas (Little Rock) & $1,761.8$ & 15.1 \\
\hline Georgia (Atlanta) & $1,635.6$ & 14.0 \\
\hline Alabama (Birmingham) & $1,409.9$ & 12.1 \\
\hline North Carolina (Raleigh) & $1,198.8$ & 10.3 \\
\hline Mississippi (Jackson) & 786.5 & 6.7 \\
\hline $\begin{array}{l}\text { Delmarva (Salisbury, Md.) } \\
\text { (Includes Delaware and Virginia) }\end{array}$ & $1,669.5$ & 14.3 \\
\hline Texas (Dallas) & 646.7 & 5.5 \\
\hline California (Fresno) & 525.8 & 4.5 \\
\hline Pennsylvania (Harrisburg) & 334.7 & 2.9 \\
\hline Maine (Waterville) & 231.2 & 2.0 \\
\hline 10-Region Total & $10,200.5$ & 87.5 \\
\hline U.S. Total & $11,655.8$ & 100.0 \\
\hline
\end{tabular}

$\star_{\mathrm{RTC}}=$ Ready to cook. 


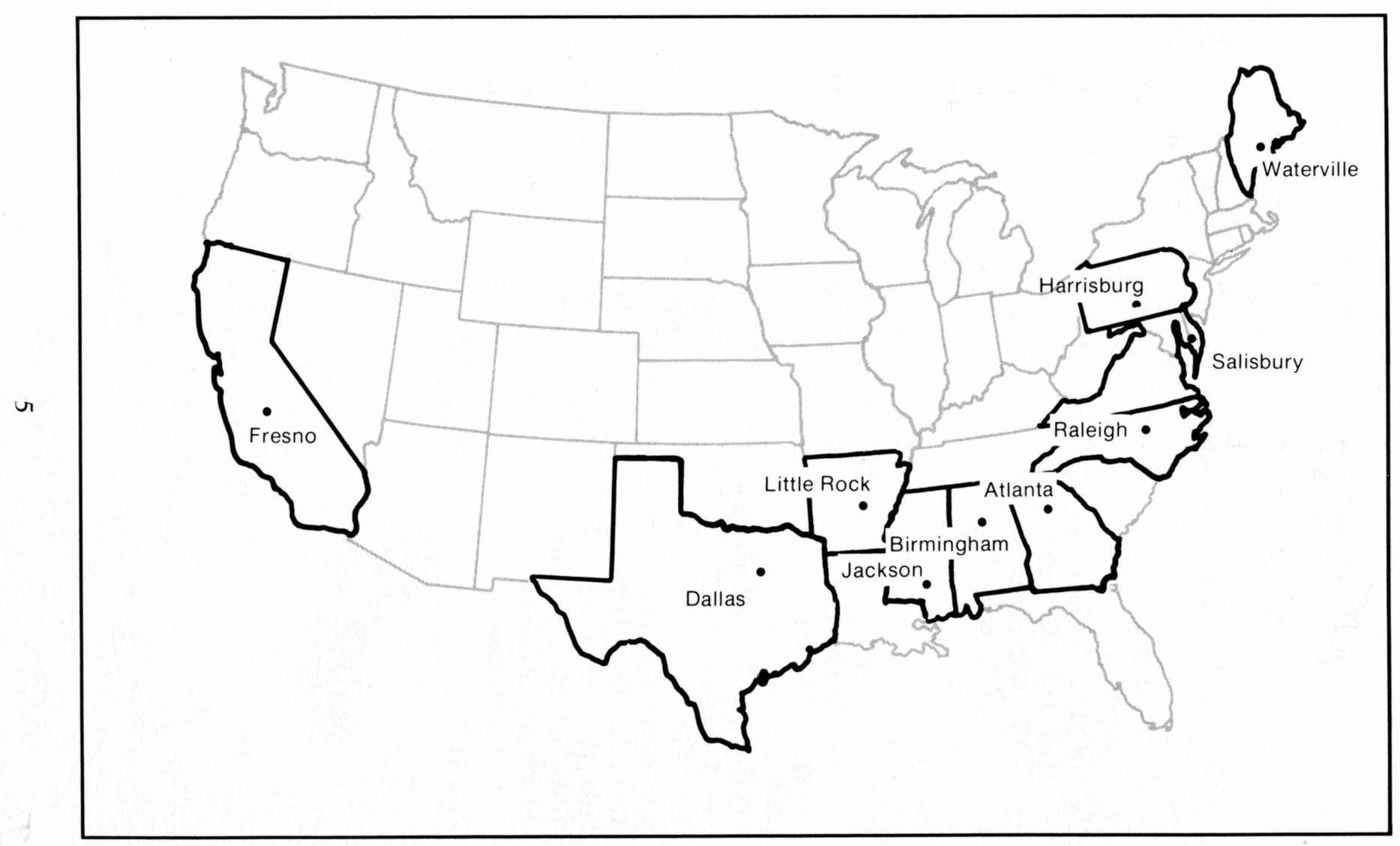

Figure 1. Broiler Production Regions and Their Representative Points. 
Table 2

Population and Broiler Consumption by

Consumption Region, 1980

\begin{tabular}{lcc}
\hline \hline & 1980 & \\
Consumption Region & Population & Consumption (RTC) \\
\hline & (thousands) & (million pounds) \\
New England (Boston) & $12,348.5$ & 579.1 \\
N.Y. (New York) & $17,557.3$ & 823.4 \\
Pa.-N.J. (Philadelphia) & $19,230.9$ & 901.9 \\
Md.-Del.-D.C. (Baltimore) & $5,449.3$ & 255.6 \\
Va.-W.Va. (Richmond) & $7,295.9$ & 342.2 \\
N.C.-S.C. (Charlotte) & $8,993.6$ & 421.8 \\
Ga.-Ala. (Atlanta) & $9,354.3$ & 438.7 \\
Fla. (Tampa) & $9,740.0$ & 456.8 \\
Mich. (Detroit) & $9,258.3$ & 434.2 \\
Ohio-Ind. (Columbus) & $16,287.6$ & 763.9 \\
Ind.-Ky. (Nashville) & $8,252.2$ & 387.0 \\
Ill.-Wis. (Chicago) & $16,123.8$ & 756.2 \\
Miss.-La.-Ark. (Jackson) & $9,010.1$ & 422.6 \\
Minn.-S.D.-N.D. (Minneapolis) & $5,420.0$ & 254.2 \\
Mo.-Iowa (Springfield) & $7,830.8$ & 367.3 \\
Kan.-Neb. (Topeka) & $3,933.2$ & 184.5 \\
Tex.-Okla. (Dallas) & $17,253.6$ & 809.2 \\
Mont.-Id.-Wyo. (Billings) & $2,201.4$ & 103.2 \\
Colo.-N.M. (Denver) & $4,188.8$ & 196.5 \\
Ariz.-Utah-Nev. (Phoenix) & 233.5 \\
Ore.-Wash. (Portland) & $4,978.1$ & 317.2 \\
Calif. (Los Angeles) & $6,762.8$ & 110.1 \\
TOTALS & $23,668.6$ & 559.1 \\
\hline
\end{tabular}




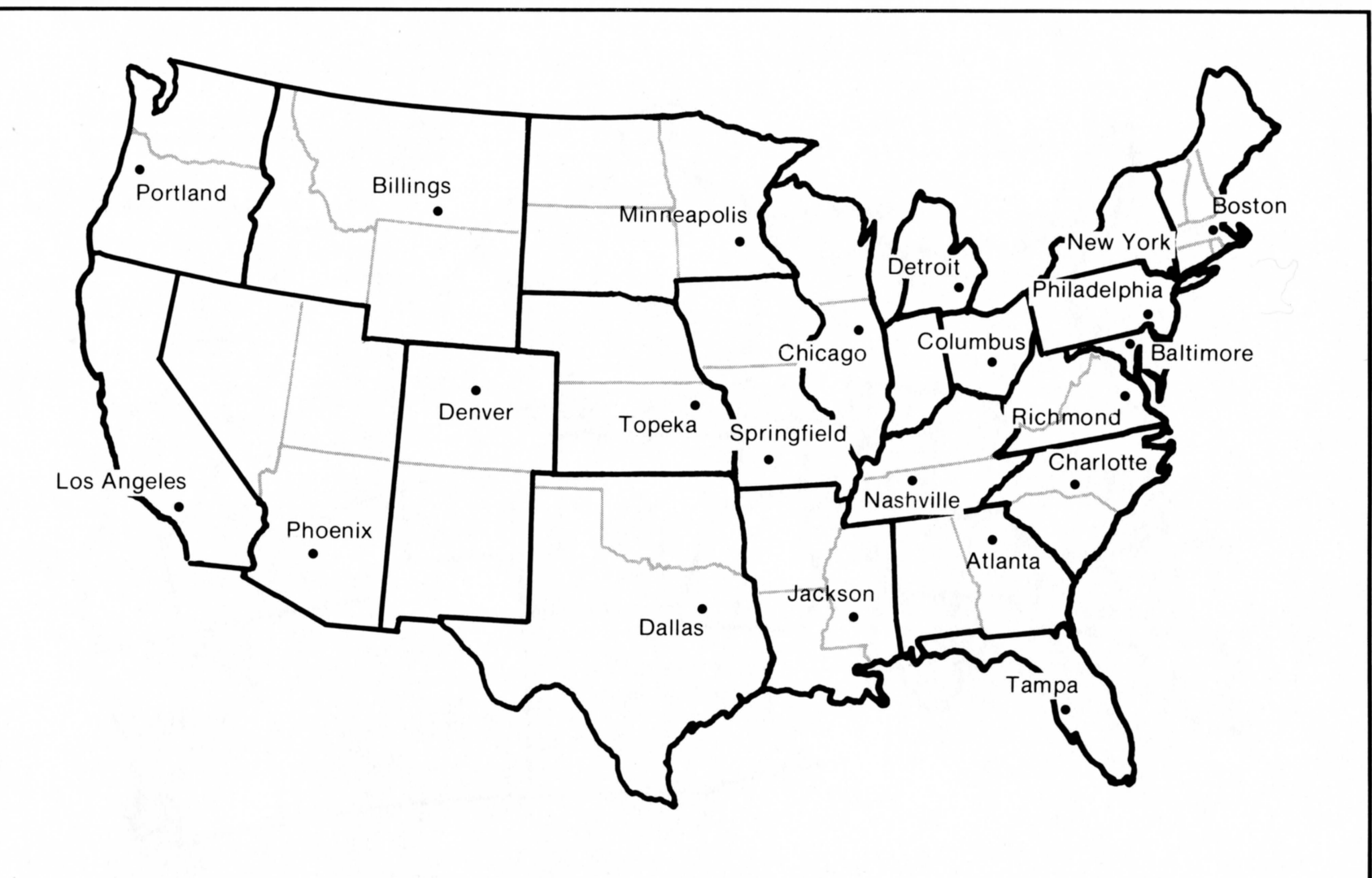




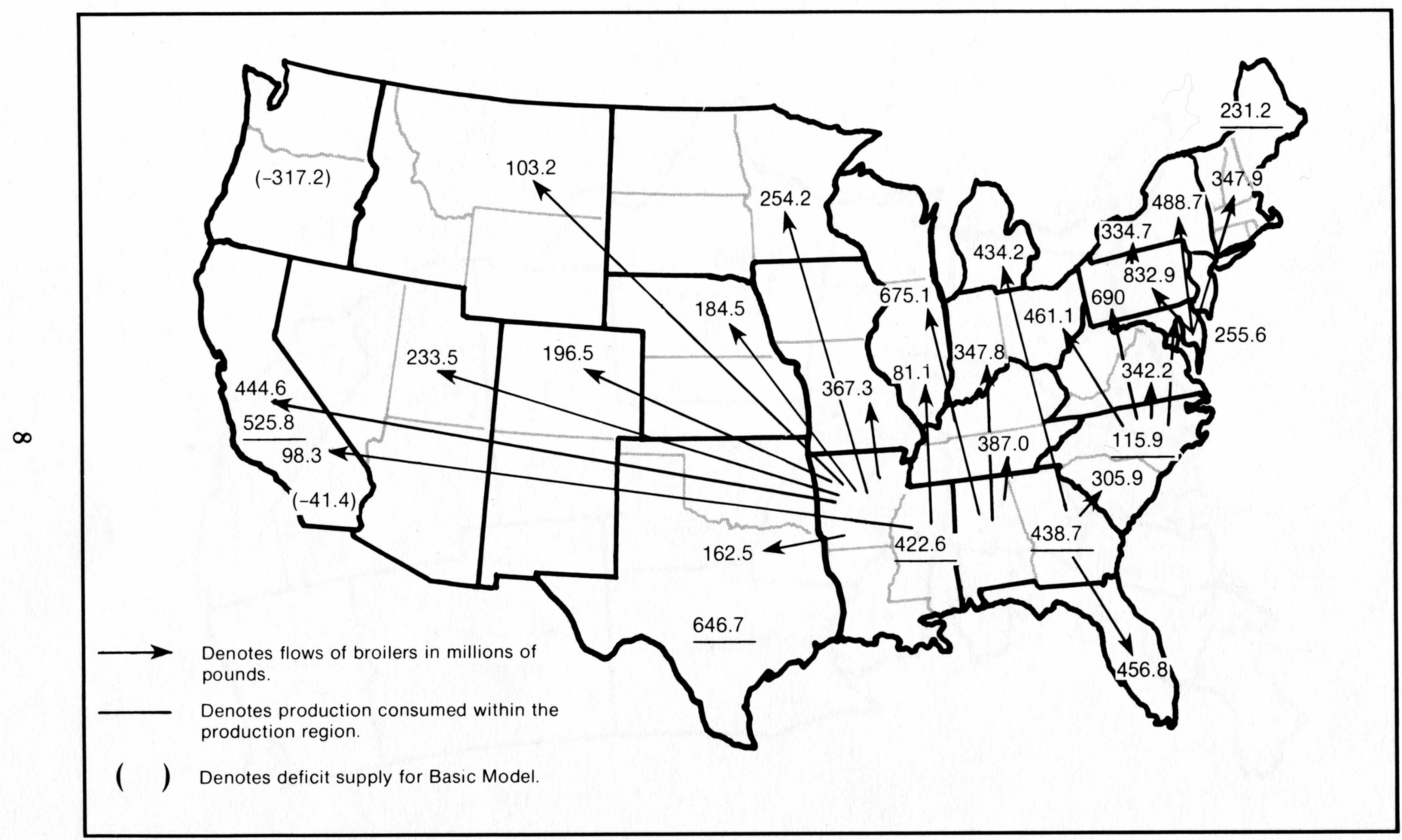

Figure 3. Least-cost Interregional Shipments for the Basic Model. 
Table 3

Interregional Movements of Broilers, 1975^

\begin{tabular}{|c|c|c|c|c|c|c|c|c|}
\hline \multirow[b]{2}{*}{$\begin{array}{l}\text { Production } \\
\text { Region }\end{array}$} & \multicolumn{8}{|c|}{ Consumption Regions } \\
\hline & $\begin{array}{c}\text { New } \\
\text { England }\end{array}$ & $\begin{array}{l}\text { Middle } \\
\text { Atlantic }\end{array}$ & $\begin{array}{c}\text { East } \\
\text { North } \\
\text { Central } \\
\end{array}$ & $\begin{array}{c}\text { West } \\
\text { North } \\
\text { Central }\end{array}$ & $\begin{array}{c}\text { South } \\
\text { Atlantic } \\
\end{array}$ & $\begin{array}{c}\text { South } \\
\text { Central } \\
\end{array}$ & Mountain & Pacific \\
\hline & \multicolumn{8}{|c|}{ (million pounds, RTC equivalent) } \\
\hline New England & 169.2 & 65.9 & - & - & - & - & - & - \\
\hline Middle Atlantic & - & 193.2 & 14.3 & - & - & - & - & - \\
\hline South Atlantic & 259.1 & $1,124.4$ & 473.1 & 113.2 & $1,225.3$ & - & - & - \\
\hline South Central & - & - & 891.2 & 376.8 & - & $1,250.2$ & 350.5 & 615.5 \\
\hline Pacific & - & - & - & - & - & - & - & 366.3 \\
\hline \multicolumn{9}{|l|}{ East North } \\
\hline Central & - & - & 110.6 & - & - & - & - & - \\
\hline \multicolumn{9}{|l|}{ West North } \\
\hline Central & - & - & - & 116.5 & - & - & - & - \\
\hline Mountain & - & - & - & - & - & - & - & - \\
\hline
\end{tabular}

*Includes broilers in ready-to-cook and further-processed forms.

Table 4

Interregional Movements of Broilers for the Basic

Model, 1980*

\begin{tabular}{|c|c|c|c|c|c|c|c|c|}
\hline \multirow[b]{2}{*}{$\begin{array}{l}\text { Production } \\
\text { Region }\end{array}$} & \multicolumn{8}{|c|}{ Consumption Regions } \\
\hline & $\begin{array}{c}\text { New } \\
\text { England }\end{array}$ & $\begin{array}{c}\text { Middle } \\
\text { Atlantic } \\
\end{array}$ & $\begin{array}{c}\text { East } \\
\text { North } \\
\text { Central } \\
\end{array}$ & $\begin{array}{c}\text { West } \\
\text { North } \\
\text { Central } \\
\end{array}$ & $\begin{array}{c}\text { South } \\
\text { Atlantic }\end{array}$ & $\begin{array}{l}\text { South } \\
\text { Central }\end{array}$ & Mountain & Pacific \\
\hline & \multicolumn{8}{|c|}{ (million pounds, RTC equivalent) } \\
\hline New England & 231.2 & - & - & - & - & - & - & - \\
\hline Middle Atlantic & - & 334.7 & - & - & - & - & - & - \\
\hline South Atlantic & 347.9 & $1,390.6$ & 416.1 & - & $1,915.1^{\star}$ & - & - & - \\
\hline South Central & - & - & $1,023.9$ & 806.0 & - & $1,618.8$ & 533.2 & 542.9 \\
\hline Pacific & - & - & - & - & - & - & - & 525.8 \\
\hline
\end{tabular}

^Includes 182.4 million pounds shipped to Alabama. 


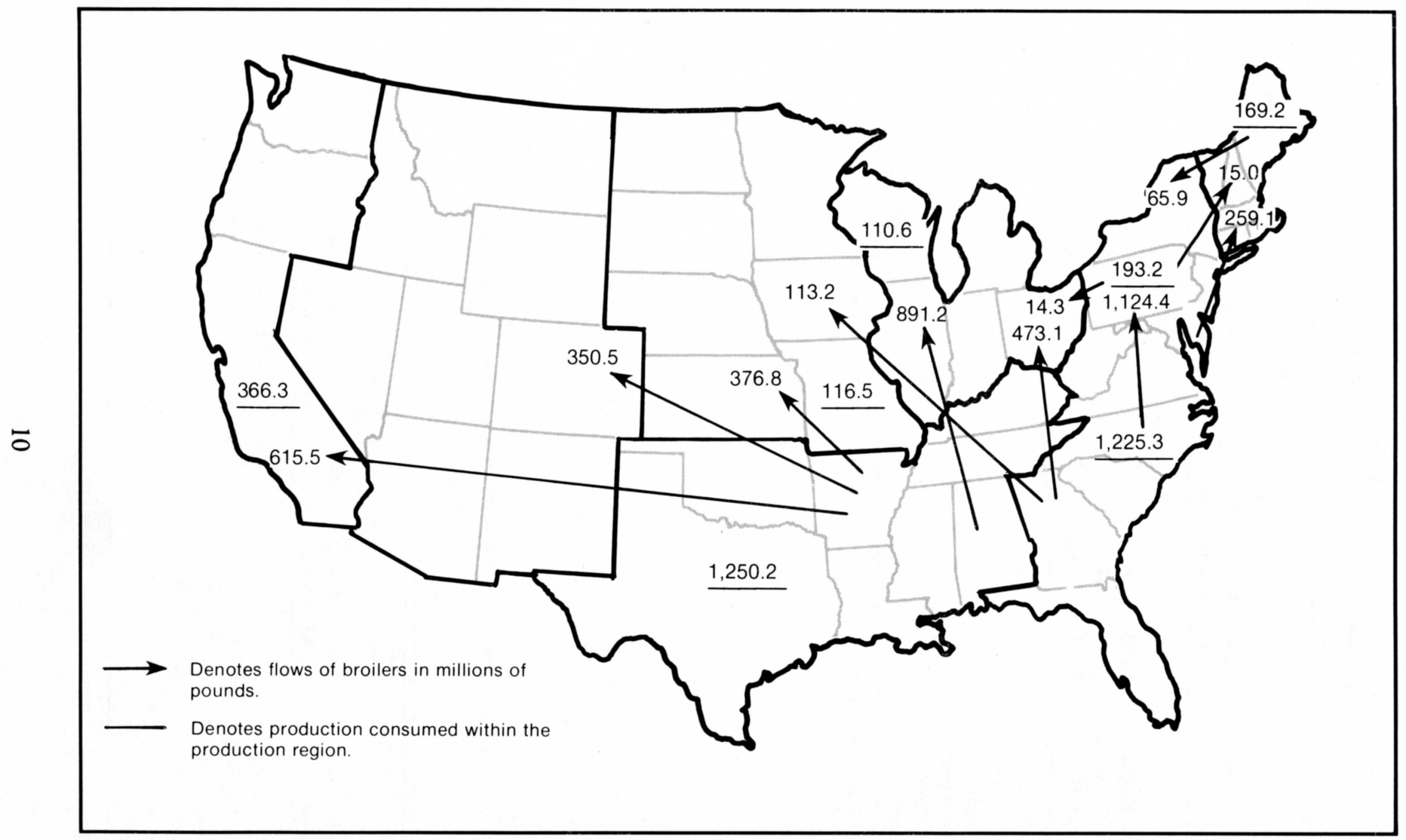

Figure 4. Interregional Movements of Broilers, 1975. 


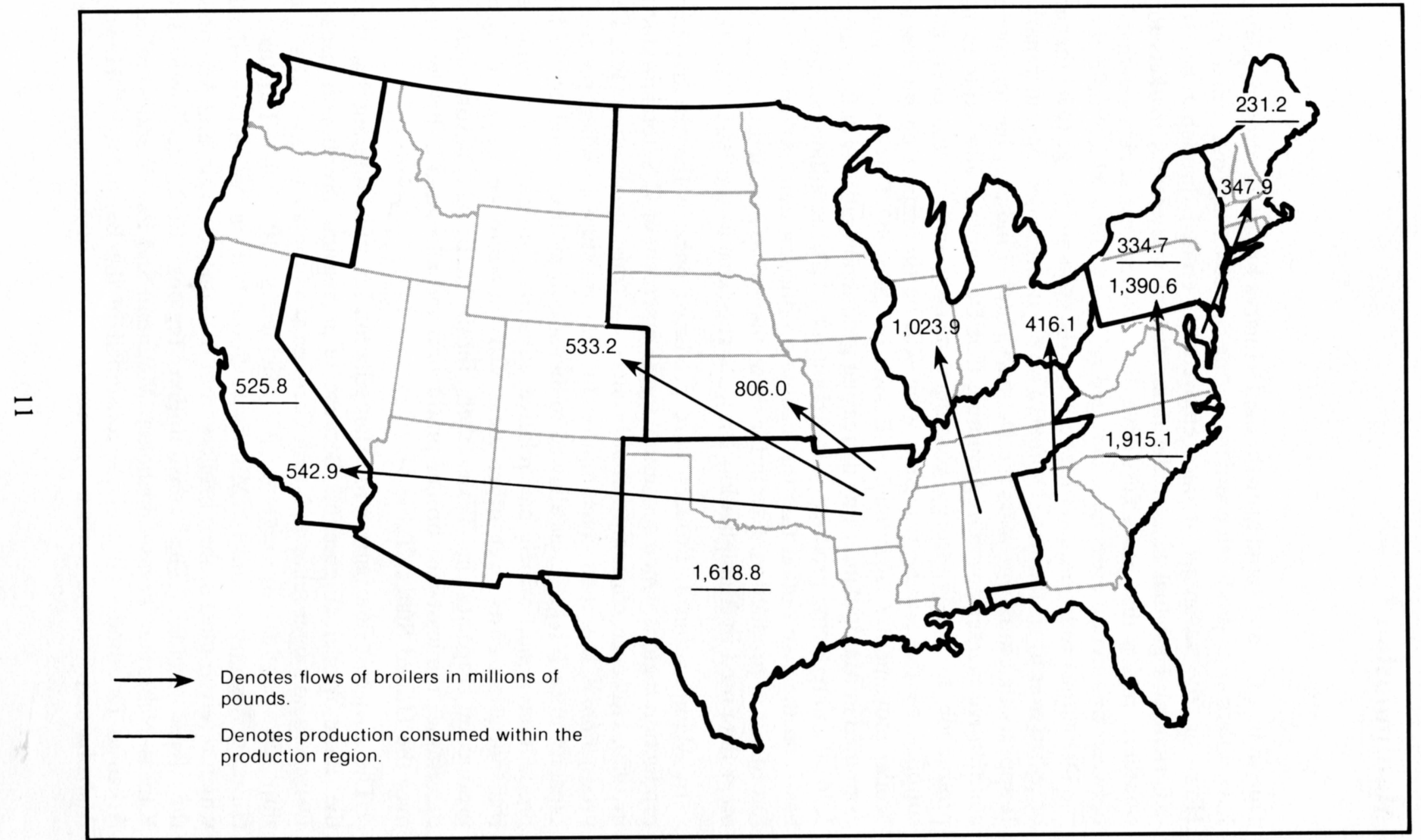

Figure 5. Interregional Movements of Broilers for the Basic Model, 1980. 


\section{Manipulation I}

Due to its early and rapid growth, the Delmarva broiler industry appeared to have a long-time production and marketing cost advantage over other regions. However, the advantage it once enjoyed has eroded through time. It has experienced a gradual loss of the more distant midwestern markets to the Southern region that has a cost advantage. Nevertheless, cost relationships between production areas have changed relative to 1967 which indicates that the Delmarva broiler industry has reduced the costs advantage that other areas once had over it. In addition, Delmarva is near many major consumer markets. It appears that in recent years the Delmarva broiler industry has improved its competitive market position. Assuming that Delmarva is allowed to increase production to satisfy nearby consumer markets which have been mostly supplied by the Southern region, what will be the impact on interregional broiler movements? How much will costs be changed? This assumption was examined in Manipulation I by increasing production capacity of Delmarva by 1,761.8 and reducing production in Arkansas by $1,761.8$ million pounds (RTC basis) on the assumption that the leading production state, Arkansas, will be forced out of production. Except for these changes in production capacity, all other data used in Manipulation I remain the same as the Basic Model.

In Manipulation I, broilers were produced only in the ten designated production regions which accounted for 87.5 percent of U.S. total production in 1980 . However, consumption of broilers was considered nationwide. Thus, production is less than consumption in Manipulation I. When production capacity in each region was allowed to increase to meet the total demand, the production region which has relative advantage in both production and transportation costs over other areas was found to be Texas. Increased production capacity in Texas then fulfills national consumption and determines the least-cost broiler production and allocation of broiler supply over the United States (Table 5).

The least-cost flow pattern for Manipulation I is quite different than that of the Basic Model (Figure 6). Because of increasing production capacity, Delmarva no longer relies on North Carolina as a supplier and instead is able to ship its surplus to regions 9 (Michigan), 10 (Ohio-Indiana), 12 (Illinois-Wisconsin), and 14 (Minnesota-South Dakota-North Dakota), all of which received most of their broilers from Alabama, Georgia, and Arkansas in the Basic Model. The consumption regions 15-22 (Missouri-Iowa, Kansas-Nebraska, Texas-Oklahoma, Mountain and Pacific states) relied on Arkansas for almost all broilers consumed in the Basic Model. However, Alabama and Georgia replace Arkansas's position in Manipulation I due to 
Table 5

Least-cost Broiler Production by Region for Manipulation I

\begin{tabular}{lccr}
\hline \hline $\begin{array}{l}\text { Production } \\
\text { Region }\end{array}$ & \multicolumn{1}{c}{$\begin{array}{c}\text { Basic } \\
\text { Production }\end{array}$} & $\begin{array}{c}\text { Increasing } \\
\text { Production }\end{array}$ & $\begin{array}{c}\text { Total } \\
\text { Production }\end{array}$ \\
\hline Arkansas & \multicolumn{4}{c}{ (million pounds RTC) } \\
Georgia & 0 & 0 & 0 \\
Alabama & $1,635.6$ & 0 & $1,635.6$ \\
North Carolina & $1,409.9$ & 0 & $1,409.9$ \\
Mississippi & $1,198.8$ & 0 & $1,198.8$ \\
Delmarva & 786.5 & 0 & 786.5 \\
Texas & $3,431.3(1,669.5+1,761.8)$ & 0 & $3,431.3$ \\
California & 646.7 & 358.6 & $1,005.3$ \\
Pennsylvania & 525.8 & 0 & 525.8 \\
Maine & 334.7 & 0 & 334.7 \\
Total & 231.2 & 0 & 231.2 \\
& $10,200.5$ & 358.6 & $10,559.1$ \\
\hline
\end{tabular}

Arkansas being forced out of production. Texas changes from a deficit to a surplus region in Manipulation I, because the production capacity is allowed to increase in each region. This surplus was shipped to region 20 (Arizona-Utah-Nevada).

The aggregate production and transportation cost in Manipulation I was $\$ 6,044.2$ million. The $\$ 241.8$ million increase in the aggregate cost over the Basic Model was mainly the result of increasing production in the relatively high production cost region, Delmarva, and allowing the production capacity in Texas to increase to fulfill the total demand of the country. 


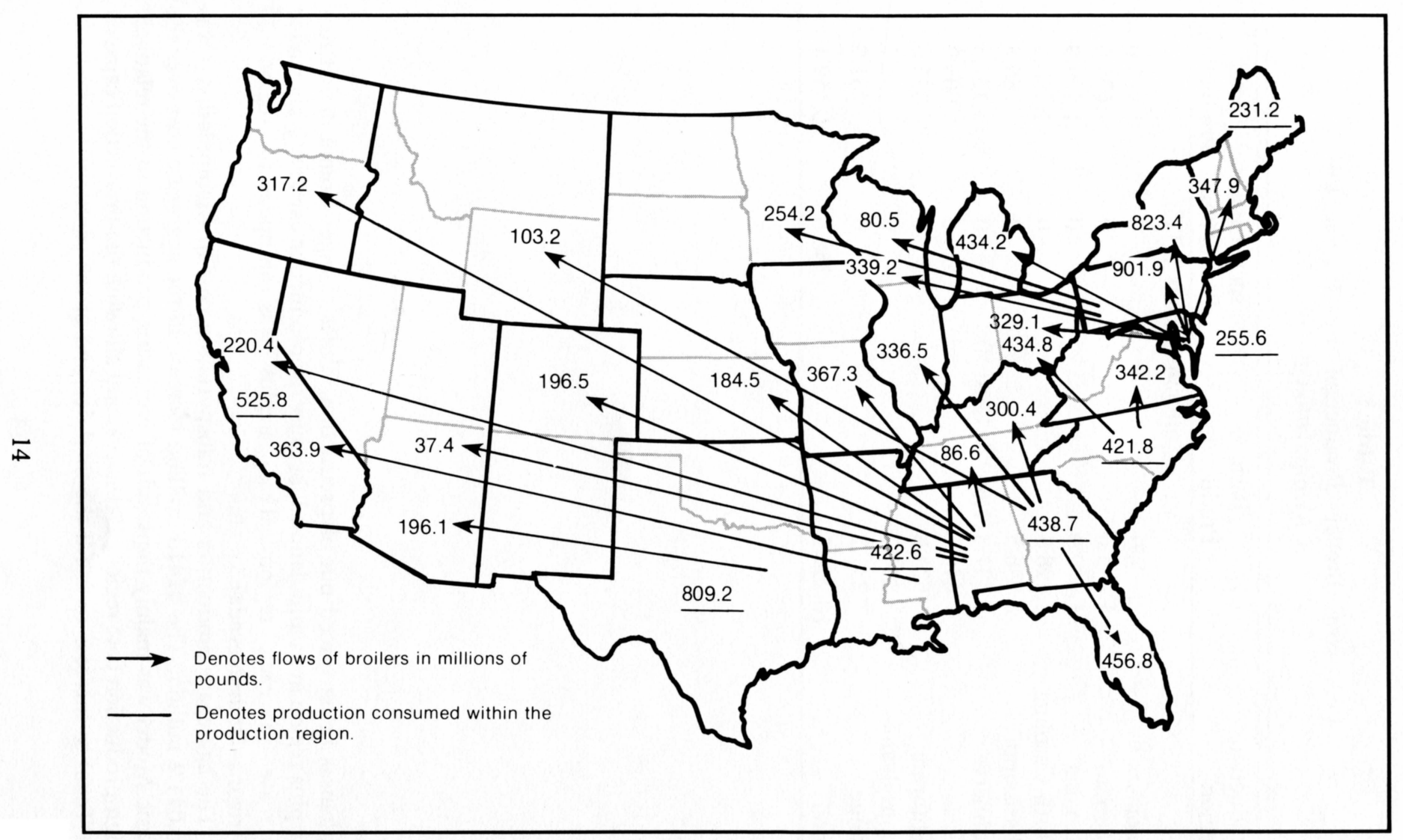

Figure 6. Least-cost Interregional Shipments for Manipulation I. 
Table 6

Least-cost Production by Region for Manipulations

II and III

\begin{tabular}{lccr}
\hline \hline $\begin{array}{l}\text { Production } \\
\text { Region }\end{array}$ & $\begin{array}{c}\text { Basic } \\
\text { Production }\end{array}$ & $\begin{array}{c}\text { Increasing } \\
\text { Production }\end{array}$ & $\begin{array}{c}\text { Total } \\
\text { Production }\end{array}$ \\
\hline Arkansas & \multicolumn{3}{c}{ (million pounds RTC) } \\
Georgia & $1,761.8$ & 0 & $1,761.8$ \\
Alabama & $1,635.6$ & 0 & $1,635.6$ \\
North Carolina & $1,409.9$ & 0 & $1,409.9$ \\
Mississippi & $1,198.8$ & 0 & $1,198.8$ \\
Delmarva & 786.5 & 0 & 786.5 \\
Texas & $1,669.5$ & 0 & $1,669.5$ \\
California & 646.7 & 358.6 & $1,005.3$ \\
Pennsylvania & 525.8 & 0 & 525.8 \\
Maine & 334.7 & 0 & 334.7 \\
Total & 231.2 & 0 & 231.2 \\
\hline
\end{tabular}

\section{Manipulation II}

Transportation costs restrict interregional competition and give locational advantage to producers near densely populated consumer market areas. The transportation costs of broilers have been increasing continuously due to increased prices for fuel, for trucks and refrigeration units. The effect of increased transportation costs is examined in Manipulation II by raising all transportation rates 10 percent. Production capacity in each region is allowed to increase to test regional comparative cost advantage. All other data used in Manipulation II are the same as those in the Basic Model.

The solution for Manipulation II showed that the basic production distribution pattern did not change significantly when transportation costs were increased by 10 percent (Figure 7). Again, Texas increased production due to its relative advantage in both production and shipping costs to fulfill the total demand (Table 6). A small amount of Delmarva surplus was redirected from New York to region 3 (Pennsylvania-New Jersey), while, oppositely, North Carolina shipped its Basic Model quantity of broilers to New York 
instead of region 3. Shipments from Mississippi to California increased substantially, and shipments from Arkansas to California decreased. Texas changed from a deficit to a surplus region and sent the surplus to region 20 (Arizona-Utah-Nevada), which received broilers from Arkansas in the Basic Model. From the solution it appears that the broiler industry is not very sensitive to a 10 percent change in the regional transportation costs.

The aggregate cost of production and transportation in Manipulation II was $\$ 6,026.1$ million. The $\$ 223.7$ million increase in aggregate cost over the Basic Model was the result of increasing transportation cost, and allowing the production capacity in Texas to increase to satisfy the total demand.

\section{Manipulation III}

Feed cost has accounted for almost 70 percent of the total cost of broiler production since 1973. There are several studies pointing out that low cost barge transportation into the South provides lower feed cost and competition for railroads and trucks. In Manipulation III, the possibility of a cost advantage for Southern production regions was examined by increasing production costs 10 percent in all other regions while costs for the Southern regions remain constant. Production capacity in each region was also allowed to increase to test the regional comparative cost advantage.

The solution to Manipulation III was very similar to that of Manipulation II (Table 6, Figure 8). Region 16 (Kansas-Nebraska) receive broilers from Mississippi in Manipulation III, which came from Arkansas in Manipulation II. On the other hand, the small quantity of broilers consumed in region 20 (Arizona-Utah-Nevada) from Mississippi in Manipulation II came from Arkansas in Manipulation III. The major source of supply for the California market shifted from Mississippi to Arkansas. Generally speaking, the flow patterns of Manipulation II and III are similar, but Manipulation III is more similar to the Basic Model. It appears that a 10 percent production cost advantage in the Southern states would not alter the current interregional competitive position of the broiler industry significantly.

The aggregate cost of production and transportation in Manipulation III was $\$ 6,134.5$ million. The $\$ 332.0$ million increase in aggregate cost over the Basic Model was the result of increased production costs in four production regions (Delmarva, California, Pennsylvania, and Maine), and of allowing the production capacity in Texas to increase to satisfy the total demand. 


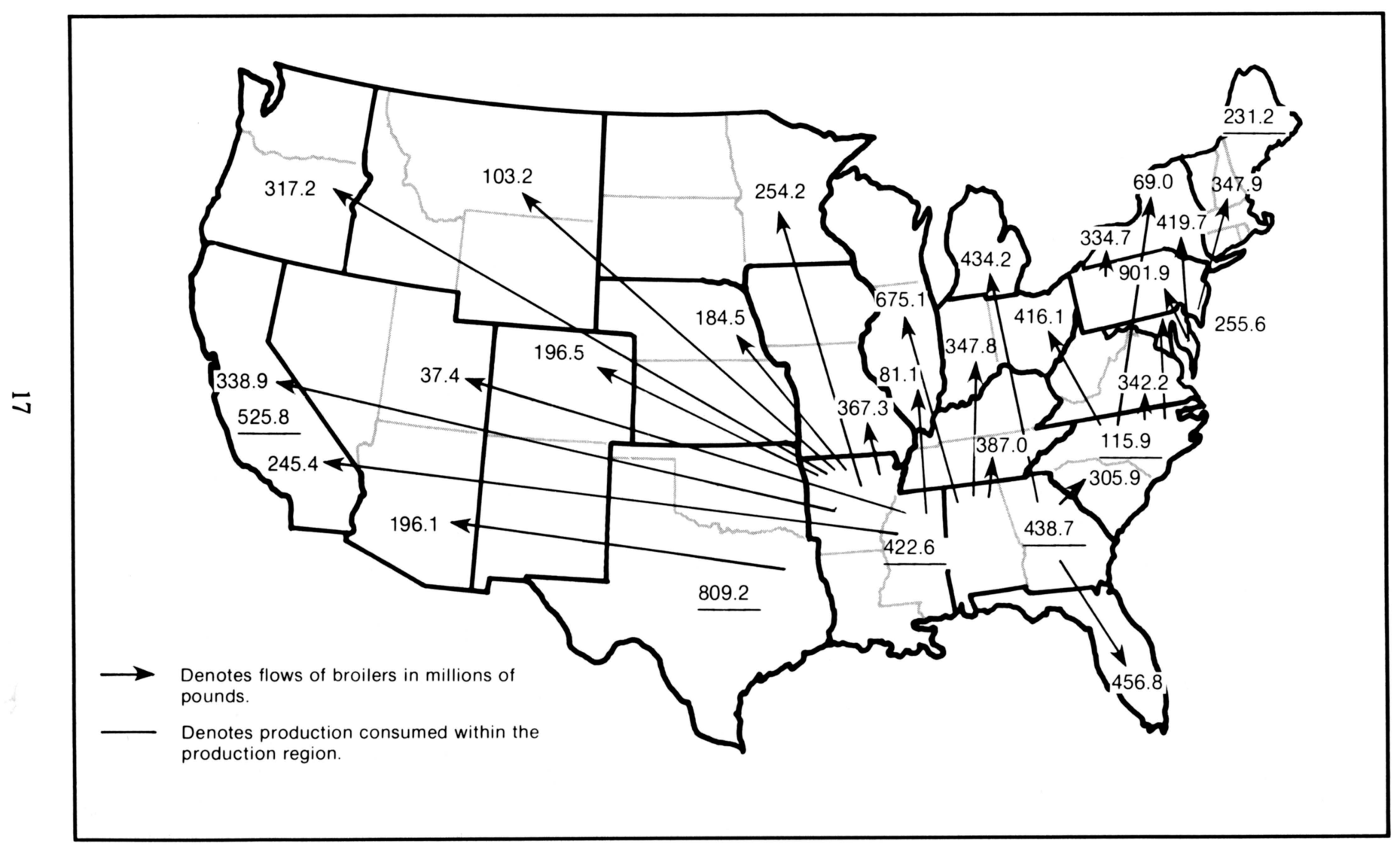

Figure 7. Least-cost Interregional Shipments for Manipulation II. 


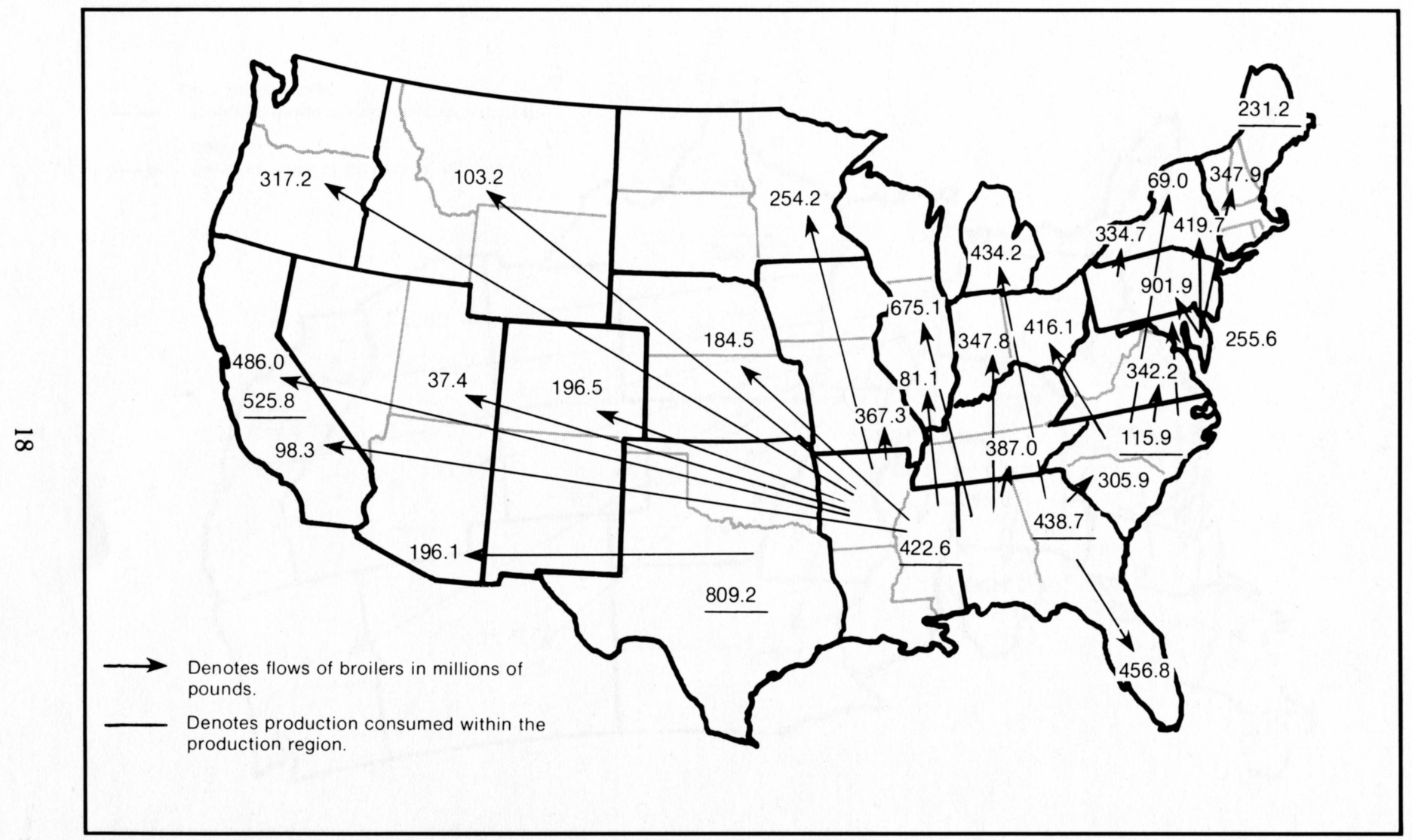

Figure 8. Least-cost Interregional Shipments for Manipulation III. 


\section{Table 7}

Least-cost Broiler Production by Region for Manipulation IV

\begin{tabular}{lrcr}
\hline \hline $\begin{array}{l}\text { Production } \\
\text { Region }\end{array}$ & $\begin{array}{c}\text { Basic } \\
\text { Production }\end{array}$ & $\begin{array}{c}\text { Increasing } \\
\text { Production }\end{array}$ & $\begin{array}{c}\text { Total } \\
\text { Production }\end{array}$ \\
\hline \multicolumn{3}{c}{ (million pounds RTC) } \\
Arkansas & $1,654.6$ & 0 & $1,654.6$ \\
Georgia & $1,379.3$ & 229.5 & $1,149.6$ \\
Alabama & $1,227.5$ & 0 & $1,227.5$ \\
North Carolina & 923.3 & 0 & 923.3 \\
Mississippi-Louisiana & 760.5 & 512.9 & 247.6 \\
Delmarva & $1,913.1$ & 169.5 & $1,023.6$ \\
Maine & 178.5 & 178.5 & 0 \\
Total & $7,316.8$ & $1,090.4$ & $6,226.4$ \\
\hline
\end{tabular}

\section{Manipulation IV}

The initial step in developing estimates of interregional net movements between production and consumption areas is to calculate the surpluses and deficits. Total surplus or deficit figures for each region were obtained by subtracting regional consumption from regional supply. The estimated surplus regions were considered as supply areas and deficit regions were considered as demand areas for broilers in 1980 to construct Manipulation IV. The shipment pattern in Manipulation IV allocates regional surpluses among deficit areas in a manner that minimizes total cost. In the analysis, the United States was divided into 23 regions. ${ }^{5}$ Of these, 7 were surplus and 16 were deficit regions (Figures 9 and 10). Because U.S. total production was greater than total consumption in 1980 , the more distant production regions from the major consumption regions had a surplus left over after the total demand was fulfilled (Table 7).

The principal direction of shipments in the solution for Manipulation IV continued to be from south to north (Figure 11). Roughly speaking, the flow pattern was similar to the Basic Model. Due to different criteria for selecting the regions, however, it is unrealistic to make comparison between them. Production and consumption regions were regrouped by the same criteria used in the 1975 situation to make comparison (Table 8).

Figure 12 shows interregional shipments of broilers for Manipulation IV. The flow pattern is very similar to the 1975 actual situation and the Basic Model (Figures 4 and 5). This again can be interpreted to mean that the broiler industry has achieved efficiency in resource allocation. The aggregate cost of production and transportation in Manipulation IV was $\$ 3,477.2$ million.

${ }^{5}$ Excludes Alaska and Hawaii. 
Table 8

Interregional Movements of Broilers for

Manipulation IV, 1980*

\begin{tabular}{|c|c|c|c|c|c|c|c|c|}
\hline \multirow[b]{2}{*}{$\begin{array}{l}\text { Production } \\
\text { Region }\end{array}$} & \multicolumn{8}{|c|}{ Consumption Regions } \\
\hline & $\begin{array}{c}\text { New } \\
\text { England }\end{array}$ & $\begin{array}{c}\text { Middle } \\
\text { Atlantic } \\
\end{array}$ & $\begin{array}{c}\text { East } \\
\text { North } \\
\text { Central } \\
\end{array}$ & $\begin{array}{c}\text { West } \\
\text { North } \\
\text { Central }\end{array}$ & $\begin{array}{c}\text { South } \\
\text { Atlantic } \\
\end{array}$ & $\begin{array}{c}\text { South } \\
\text { Central }\end{array}$ & Mountain & Pacific \\
\hline & \multicolumn{8}{|c|}{ (million pounds, RTC equivalent) } \\
\hline New England & 52.7 & - & - & - & - & - & - & - \\
\hline Middle Atlantic & - & 334.7 & - & - & - & - & - & - \\
\hline South Atlantic & 526.4 & $1,420.7$ & $931.0^{\star}$ & - & $1,611.3$ & - & - & - \\
\hline South Central & - & - & 931.3 & 652.0 & - & $1,801.2$ & 495.8 & $820.1^{\dagger}$ \\
\hline Pacific & - & - & - & - & - & - & - & 644.7 \\
\hline \multicolumn{9}{|l|}{ East North } \\
\hline Central & - & - & $183.4^{\star}$ & - & - & - & - & - \\
\hline \multicolumn{9}{|l|}{ West North } \\
\hline Central & - & - & - & 153.7 & - & - & - & - \\
\hline Mountain & - & - & - & - & - & - & - & - \\
\hline
\end{tabular}

*Includes production or consumption of West Virginia.

†Includes consumption of Nevada.

\section{Manipulation V}

In order to determine the demand induced direction of broiler industry growth, population and per capita consumption were projected to find regional consumption for 1990. U.S. Bureau of the Census population estimates of 1990 were used for regional population estimates. Regional consumption was estimated by several methods. Three sets of projected regional consumption figures were used in Manipulation V, VI, and VII, respectively.

In Manipulation V, per capita broiler consumption was projected to be 58.6 pounds for the United States. Projected regional broiler consumption for 1990 is then reached by multiplying projected regional population by projected per capita consumption, which is $\mathbf{5 8 . 6}$ pounds per capita.

The 1980 regional broiler production was used as initial regional production capacity and then the production capacity in each region was allowed to increase to meet the total future demand in Manipulation V. The value of such a Manipulation is that the production regions that have relative cost advantages over other areas will be found. These are Texas and North Carolina in this case. Increased production in Texas and North Carolina will then satisfy national consumption and determine the least-cost broiler production and allocation of broiler supply over the United States (Table 9). 


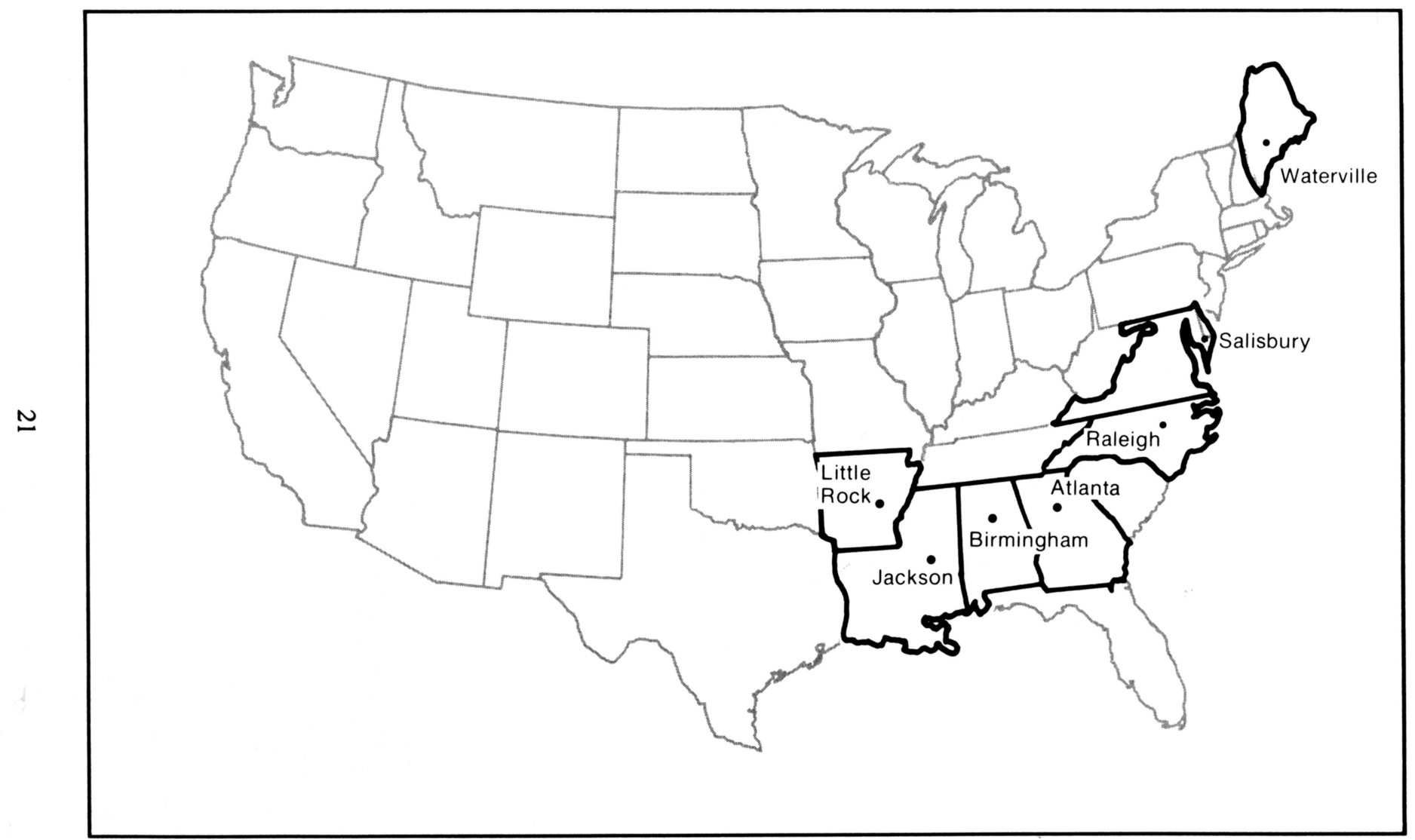

Figure 9. Broilers Surplus Regions and Their Representative Points. 


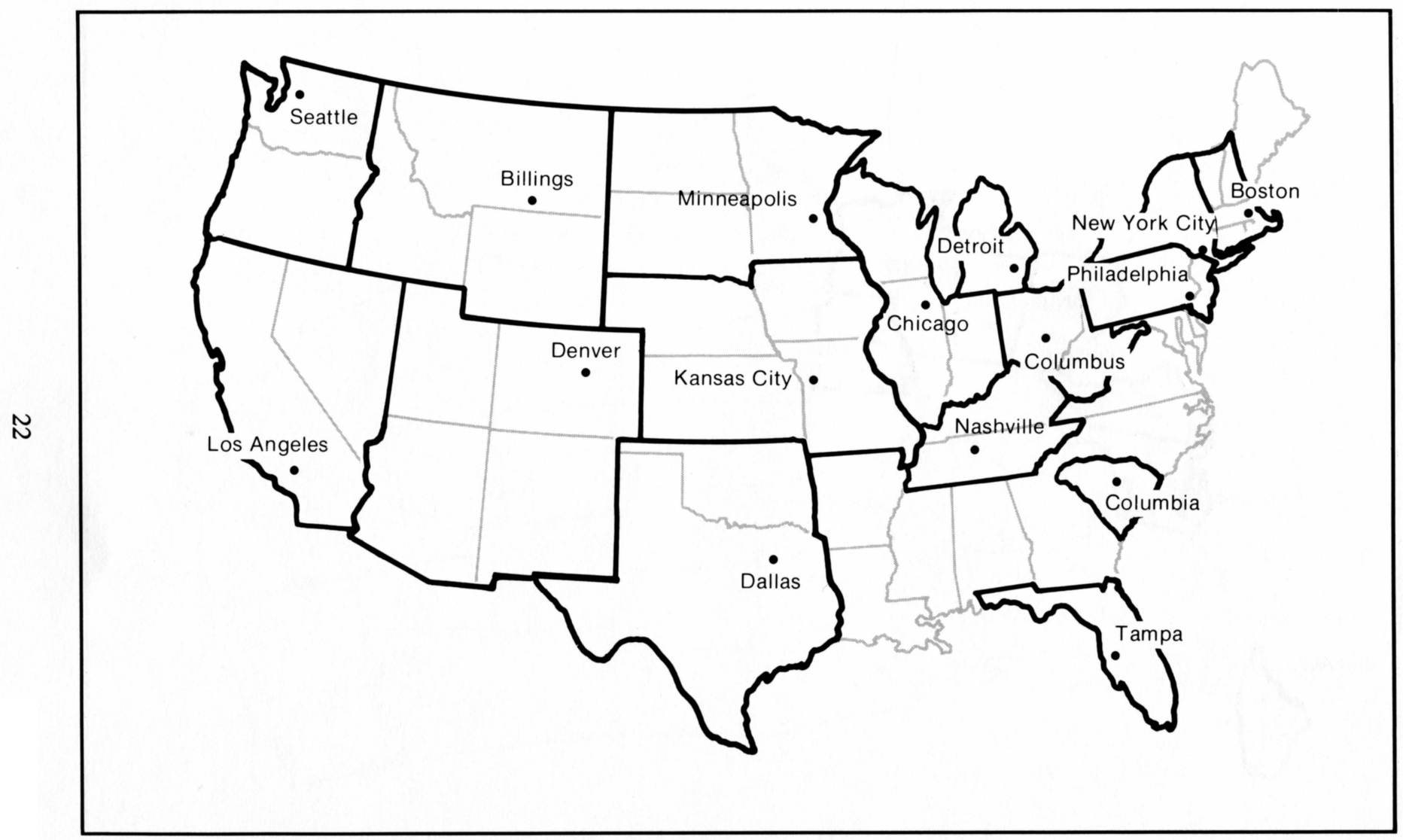

Figure 10. Broilers Deficit Regions and Their Representative Points. 


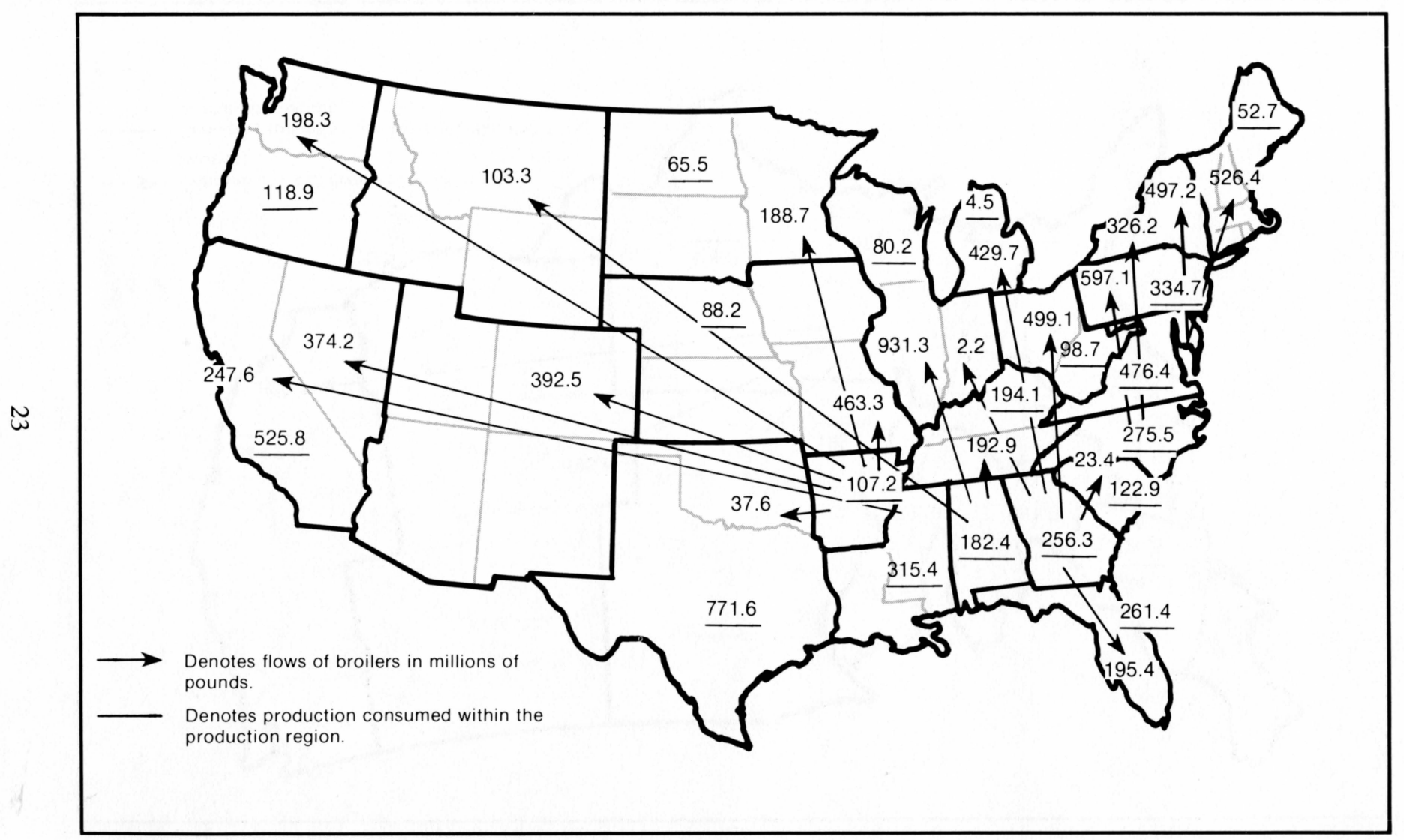

Figure 11. Least-cost Interregional Shipments for Manipulation IV. 


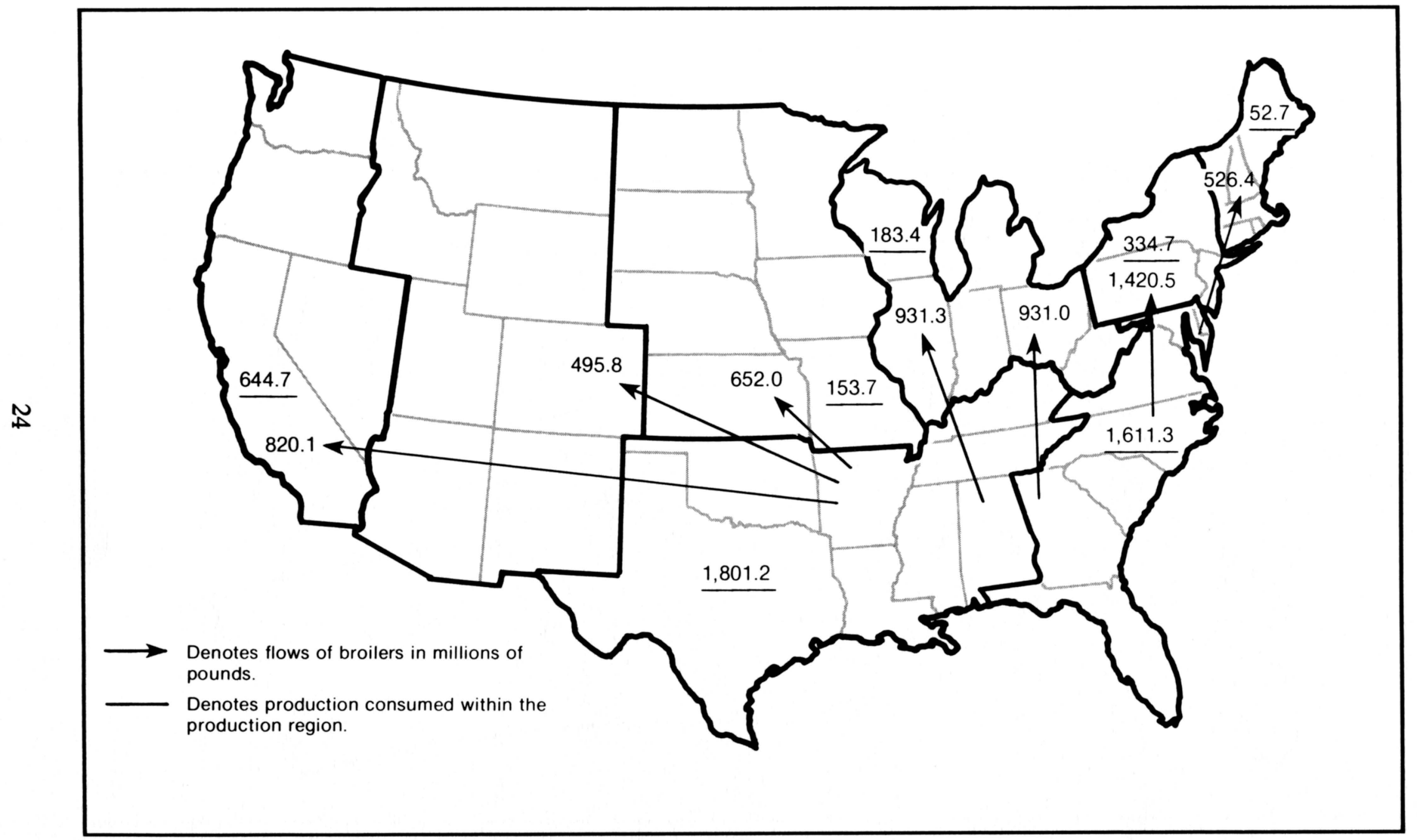

Figure 12. Interregional Movements of Broilers for Manipulation IV, 1980. 


\section{Table 9}

Least-cost Broiler Production by Region for Manipulation V

\begin{tabular}{lrcr}
\hline \hline $\begin{array}{l}\text { Production } \\
\text { Region }\end{array}$ & $\begin{array}{c}\text { Basic } \\
\text { Production }\end{array}$ & $\begin{array}{c}\text { Increasing } \\
\text { Production }\end{array}$ & $\begin{array}{c}\text { Total } \\
\text { Production }\end{array}$ \\
\hline \multicolumn{4}{c}{ (million pounds RTC) } \\
Arkansas & $1,761.8$ & 0 & $1,761.8$ \\
Georgia & $1,635.6$ & 0 & $1,635.6$ \\
Alabama & $1,409.9$ & 0 & $1,409.9$ \\
North Carolina & $1,198.8$ & $1,291.8$ & $2,490.6$ \\
Mississippi & 786.5 & 0 & 786.5 \\
Delmarva & $1,669.5$ & 0 & $1,669.5$ \\
Texas & 646.7 & $2,313.8$ & $2,960.5$ \\
California & 525.8 & 0 & 525.8 \\
Pennsylvania & 334.7 & 0 & 334.7 \\
Maine & 231.2 & 0 & 231.2 \\
Total & $10,200.5$ & $3,605.6$ & $13,806.1$ \\
\hline
\end{tabular}

An alternative was constructed by increasing regional production capacity 30 percent and then production capacity in each region was allowed to increase to meet the supply requirement. ${ }^{6}$ The solution in this alternative showed that Manipulation $\mathrm{V}$ was more efficient than the alternative. The aggregate costs of production and transportation for Manipulation $\mathrm{V}$ and the alternative were $\$ 7,828.9$ million and $\$ 7,860.4$ million, respectively. The $\$ 31.5$ million cost increase in the alternative over Manipulation $\mathrm{V}$ was the result of relatively higher production cost regions (West, North Atlantic, and Delmarva) being forced to increase production by 30 percent. This illustrates that production costs, as expected, are more important than transportation costs in interregional competition of the broiler industry. Production cost accounts for the major part of aggregate cost of production and transportation.

Figure 13 shows the least-cost interregional shipments of broilers for Manipulation V. The flow pattern is quite different from the Basic Model. The most notable change was that Arkansas loses region 19 (Colorado-New Mexico), 20 (Arizona-Utah-Nevada), and 22 (California) market shares to Texas, because Texas increased its production substantially. Most of California's production is shipped to region 21 (Oregon-Washington), while a large amount of broilers were shipped to California from Texas. Arkansas replaced Alabama as the most important supplier of region 12 (Illinois-Wisconsin). Shipments from North Carolina to region 3 'Projected consumption increases 30.8 percent from the 1980 to 1990 projection in Manipulation V. 
Table 10

Least-cost Broiler Production by Region for Manipulation VI

\begin{tabular}{lrcr}
\hline \hline $\begin{array}{l}\text { Production } \\
\text { Region }\end{array}$ & $\begin{array}{c}\text { Basic } \\
\text { Production }\end{array}$ & $\begin{array}{c}\text { Increasing } \\
\text { Production }\end{array}$ & $\begin{array}{c}\text { Total } \\
\text { Production }\end{array}$ \\
\hline \multicolumn{4}{c}{ (million pounds RTC) } \\
Arkansas & $1,761.8$ & 0 & $1,761.8$ \\
Georgia & $1,635.6$ & 0 & $1,635.6$ \\
Alabama & $1,409.9$ & 0 & $1,409.9$ \\
North Carolina & $1,198.8$ & $1,168.6$ & $2,367.4$ \\
Mississippi & 786.5 & 0 & 786.5 \\
Delmarva & $1,669.5$ & 0 & $1,669.5$ \\
Texas & 646.7 & $2,272.2$ & $2,918.9$ \\
California & 525.8 & 0 & 525.8 \\
Pennsylvania & 334.7 & 0 & 334.7 \\
Maine & 231.2 & 0 & 231.2 \\
Total & $10,200.5$ & $3,440.8$ & $13,641.3$ \\
\hline
\end{tabular}

(Pennsylvania-New Jersey) increased considerably, because North Carolina was the other state which increased production capacity besides Texas in Manipulation V. There was no need any more for Georgia to ship broilers to North Carolina.

\section{Manipulation VI}

Manipulation VI is similar to Manipulation V except that predicted regional consumption is estimated in a different way. A 57.9 pounds per capita broiler consumption was obtained for Manipulation VI. Thus, projected regional broiler consumption for 1990 is obtained by multiplying projected regional population by 57.9 .

The solution to Manipulation VI showed that production distribution does not change much from Manipulation V. Texas and North Carolina remain the most favorable regions to increase production to satisfy total demand (Table $10)$.

An alternative was constructed by increasing regional production capacity 30 percent and then production capacity in each region was allowed to increase to meet the supply requirement. ${ }^{7}$ The solution in this alternative showed that Manipulation VI was more efficient than the alternative. The aggregate costs of production and transportation for Manipulation VI and the alternative were

7Projected consumption increases 29.2 percent from the 1980 to 1990 projection in Manipulation VI. 


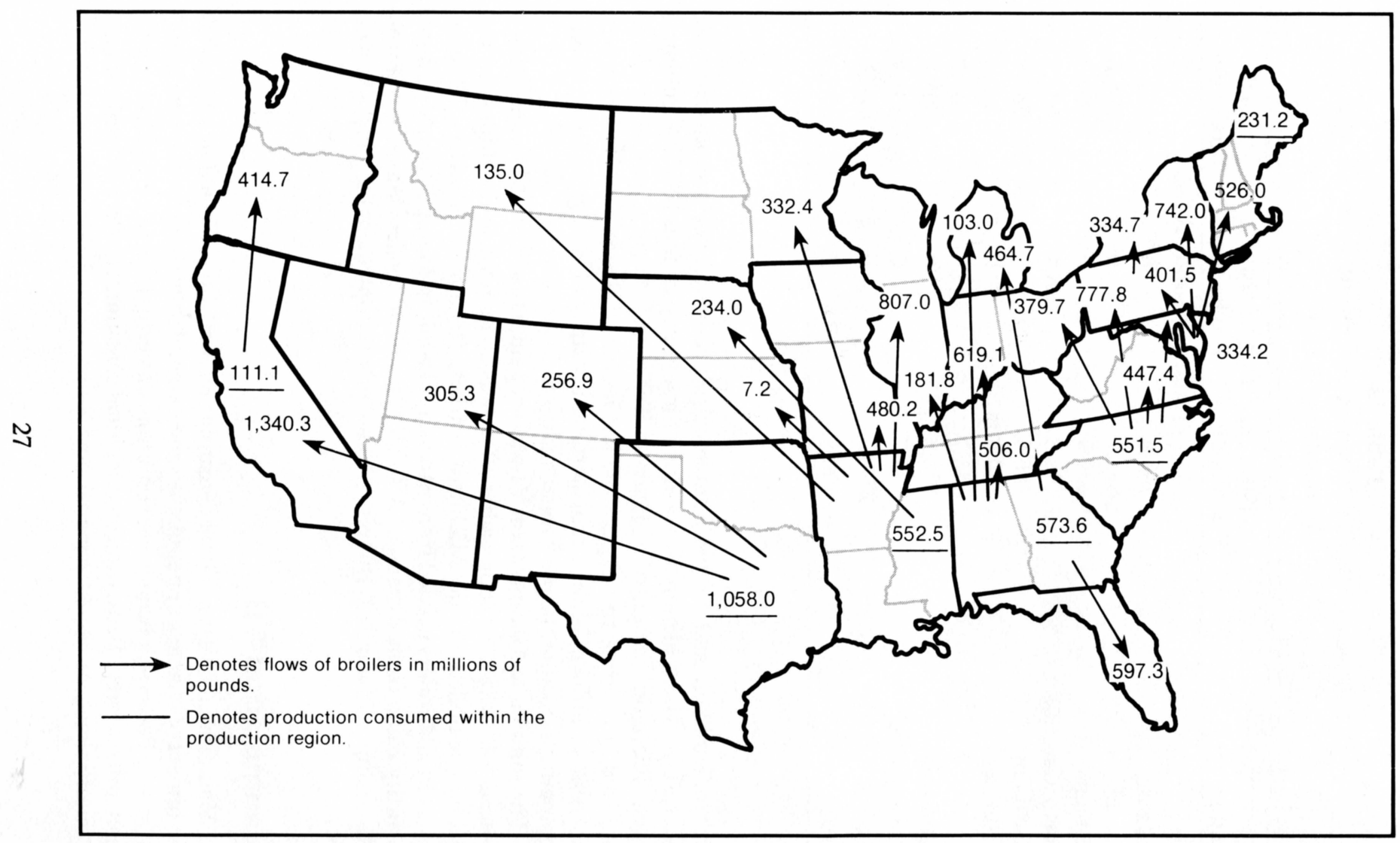

Figure 13. Least-cost Interregional Shipments for Manipulation V. 
Table 11

Least-cost Broiler Production by Region for Manipulation VII

\begin{tabular}{lrcr}
\hline \hline $\begin{array}{l}\text { Production } \\
\text { Region }\end{array}$ & $\begin{array}{c}\text { Basic } \\
\text { Production }\end{array}$ & $\begin{array}{c}\text { Increasing } \\
\text { Production }\end{array}$ & $\begin{array}{c}\text { Total } \\
\text { Production }\end{array}$ \\
\hline \multicolumn{3}{c}{ (million pounds RTC) } \\
Arkansas & $1,761.8$ & 0 & $1,761.8$ \\
Georgia & $1,635.6$ & 0 & $1,635.6$ \\
Alabama & $1,409.9$ & 0 & $1,409.9$ \\
North Carolina & $1,198.8$ & 488.4 & $1,687.2$ \\
Mississippi & 786.5 & 0 & 786.5 \\
Delmarva & $1,669.5$ & 0 & $1,669.5$ \\
Texas & 646.7 & $1,986.3$ & $2,633.0$ \\
California & 525.8 & 0 & 525.8 \\
Pennsylvania & 334.7 & 0 & 334.7 \\
Maine & 231.2 & 0 & 231.2 \\
Total & $10,200.5$ & $2,474.7$ & $12,675.2$ \\
\hline
\end{tabular}

$\$ 7,736.5$ million and $\$ 7,768.7$ million, respectively. The considerable cost decrease in Manipulation VI accounts for a yearly savings of $\$ 32.2$ million in costs. Therefore, an entry of firms in Texas and North Carolina would be expected in the long run. Again, the test indicated that production costs were much more influential than transportation costs in affecting the interregional competitive position in the broiler industry.

The solution to Manipulation VI was very similar to that of Manipulation V (Figure 14). The only appreciable effect was an increase in the shipments that Georgia supplied to the Michigan market. Region 16 (Kansas-Nebraska) received all broilers needed from Mississippi while in Manipulation V a limited quantity came from Arkansas. A small amount of broilers was shipped from Mississippi to region 12 (Illinois-Wisconsin) to supplement the supply flowing there.

\section{Manipulation VII}

In Manipulation VII, regional consumption was also projected to 1990 to test the impact of changes in population and demand induced growth on the broiler industry. Per capita broiler consumption was estimated to be 53.8 pounds for the United States. Thus, projected regional consumption for 1990 was obtained by multiplying projected regional population by 53.8 . 


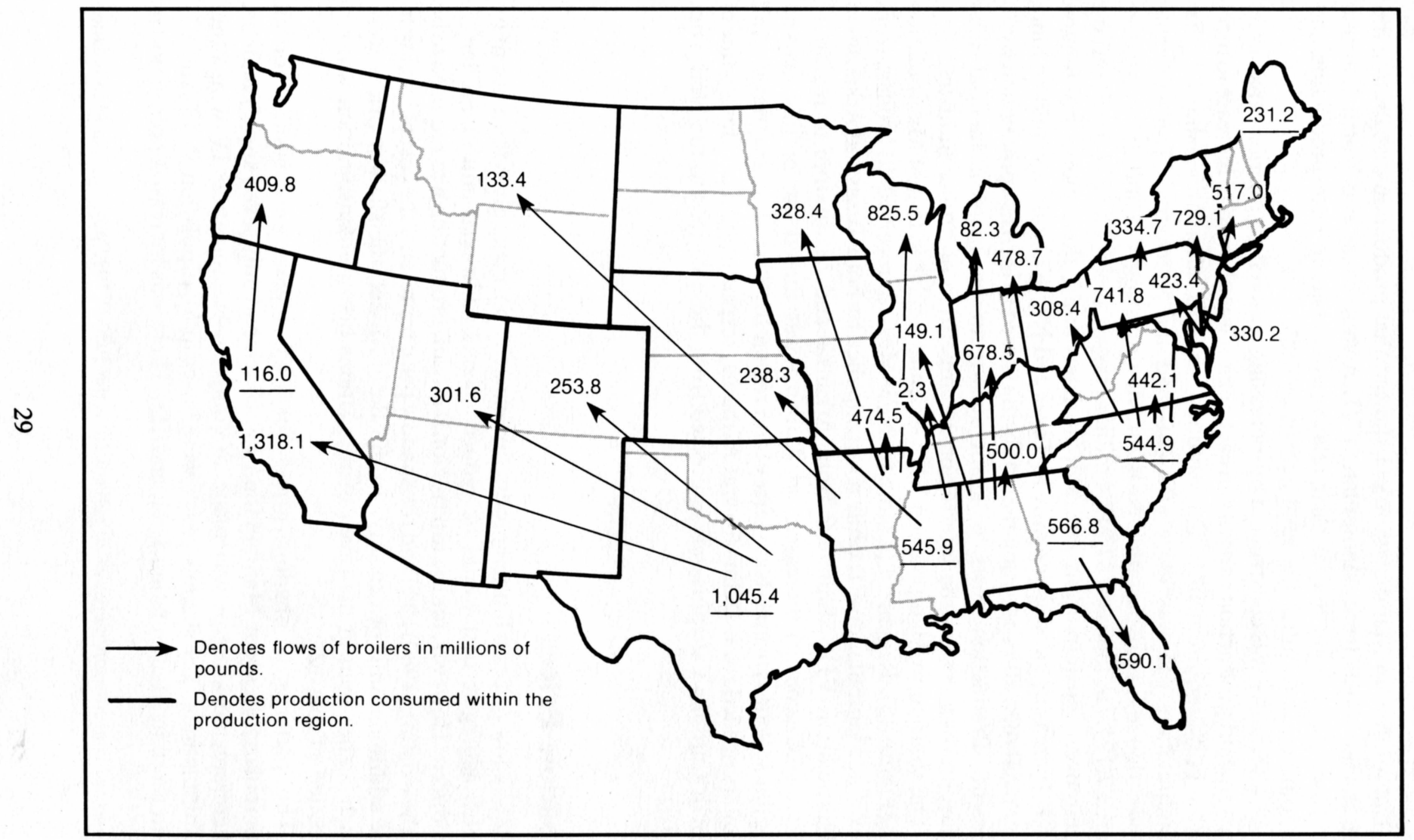

Figure 14. Least-cost Interregional Shipments for Manipulation VI. 
The solution to Manipulation VII showed that production distribution did not change much from Manipulation VI. Again, Texas and North Carolina increased production due to their relative advantage in both production and shipping costs to fulfill the total demand (Table 11).

An alternative was constructed by increasing regional production capacity 20 percent, and production capacity in each region was allowed to increase to meet the supply requirement. ${ }^{8}$ The solution in this alternative showed that Manipulation VII was more efficient than the alternative. The aggregate production and transportation costs for Manipulation VII and the alternative were $\$ 7,194.9$ million and $\$ 7,217.4$ million, respectively. The $\$ 22.5$ million cost difference is an important indicator in determining the regional production level. Increasing production only in Texas and North Carolina would be more beneficial than all production regions being forced to increase production by 20 percent. Production costs is again shown to be more influential than transportation cost in the interregional competition of broiler industry.

The solution to Manipulation VII was quite similar to that of Manipulation VI (Figure 15). Region 19 (Colorado-New Mexico) received all broilers from Texas in Manipulation VI, while it was supplied by both Texas and Arkansas in Manipulation VII. Shipments from Arkansas and Mississippi to region 12 (Illinois-Wisconsin) increased, so Alabama was forced out of this market. Region 3 (Pennsylvania-New Jersey) and region 10 (Ohio-Indiana) received all broilers needed from Delmarva and Alabama, respectively. Therefore, some of North Carolina's surplus was redirected from these regions to the New York market.

\section{Shadow Prices}

The shadow price on limited production capacity normally gives the amount by which aggregate cost would be reduced if one additional unit of broilers is produced. However, for the interregional model, production was required to be at the existing (1980) level and the shadow price represents the cost of forcing in one additional unit of capacity. In the Basic Model, the shadow prices were much higher than in the seven manipulations because consumption was not satisfied (Table 12).

The patterns of shadow prices for each region were similar for all manipulations except Manipulation IV, which had only seven supply regions. Therefore, no attempt was made to compare Manipulation IV with other manipulations. The shadow prices were lower in Manipulation V, VI, and VII than those in Manipulation I, II, and III. There was increased production in

${ }^{8}$ Projected consumption increases 20 percent from the 1980 to 1990 projection in Manipulation VII. 


\section{Table 12}

Shadow Prices on Limited Production Capacity by Region for the Basic Model and Seven Manipulations

\begin{tabular}{|c|c|c|c|c|c|c|c|}
\hline $\begin{array}{l}\text { Production } \\
\text { Region }\end{array}$ & $\begin{array}{c}\text { Basic } \\
\text { Model }\end{array}$ & $\begin{array}{c}\text { Manip- } \\
\text { ulation } \\
\text { I }\end{array}$ & $\begin{array}{c}\text { Manip- } \\
\text { ulation } \\
\text { II }\end{array}$ & $\begin{array}{c}\text { Manip- } \\
\text { ulation } \\
\text { III }\end{array}$ & $\begin{array}{l}\text { Manip- } \\
\text { ulation } \\
\text { V \& VI }\end{array}$ & $\begin{array}{c}\text { Manip- } \\
\text { ulation } \\
\text { VII }\end{array}$ & $\begin{array}{c}\text { Manip- } \\
\text { ulation } \\
I^{\star}\end{array}$ \\
\hline Arkansas & 8584.9 & $-\star \star$ & s 7.2 & $\begin{array}{ll}S & 6.5\end{array}$ & S 1.8 & S 3.1 & $\$ 2.7$ \\
\hline Georgia & 585.8 & 14.8 & 8.3 & 7.4 & 1.3 & 1.7 & $-^{+}$ \\
\hline Alabama & 585.9 & 13.7 & 8.3 & 7.5 & 1.8 & 2.2 & 1.0 \\
\hline North Carolina & 584.1 & 16.3 & 6.4 & 5.7 & $-{ }_{+}^{+}$ & $-_{+}^{+}$ & 6.7 \\
\hline Mississippi & 587.6 & 9.0 & 10.2 & 9.2 & 3.5 & 4.8 & $-^{+}$ \\
\hline Delmarva & 590.8 & 29.1 & 12.5 & 54.1 & 6.7 & 6.7 & $-{ }^{\dagger}$ \\
\hline Texas & 574.9 & -+ & -+ & -+ & $-_{+}^{+}$ & -+ & \\
\hline California & 654.1 & 75.5 & 73.4 & 125.2 & 75.1 & 75.1 & \\
\hline Pennsylvania & 633.0 & 68.8 & 54.6 & 101.0 & 48.9 & 48.9 & \\
\hline Maine & 631.1 & 69.4 & 52.4 & 99.1 & 47.0 & 47.0 & $-\dagger$ \\
\hline
\end{tabular}

$\star$ Manipulation IV only has seven supply regions.

$\star \star$ No shadow price is determined because Arkansas is forced out of production in Manipulation I.

+ Excess production exists, therefore no shadow price is determined.

$\ddagger$ Production capacity has been decreased, therefore no shadow price is determined.

Texas and North Carolina in Manipulation V, VI, and VII to satisfy the more distant markets and thus forcing additional production in the other regions would not be as costly since they would supply closer markets. The relatively high shadow price for California in all manipulations indicated that the poor competitive position of California in the broiler industry is due to higher production costs.

The shadow prices for the consumption regions indicate the amount by which aggregate cost would decrease if consumption were decreased by one unit in the respective regions (Table 13). In the Basic Model, no shadow prices were determined in region 21 (Oregon-Washington) and California and was negative in the other regions since the consumption was not satisfied in those two regions. Interpretation of the shadow prices in the Basic Model presents problems since not all the requirements of the model were met.

The shadow prices for each consumption region were similar for all manipulations, except for Manipulation IV. No excess production existed, therefore aggregate cost would be increased if one additional unit of broilers were to be consumed. The Oregon-Washington region was located relatively far from major production regions, so its shadow prices were the highest among all consumption regions.

As stated, increasing prices for beef and pork during the past several decades were accompanied by increasing broiler consumption rates. While average 


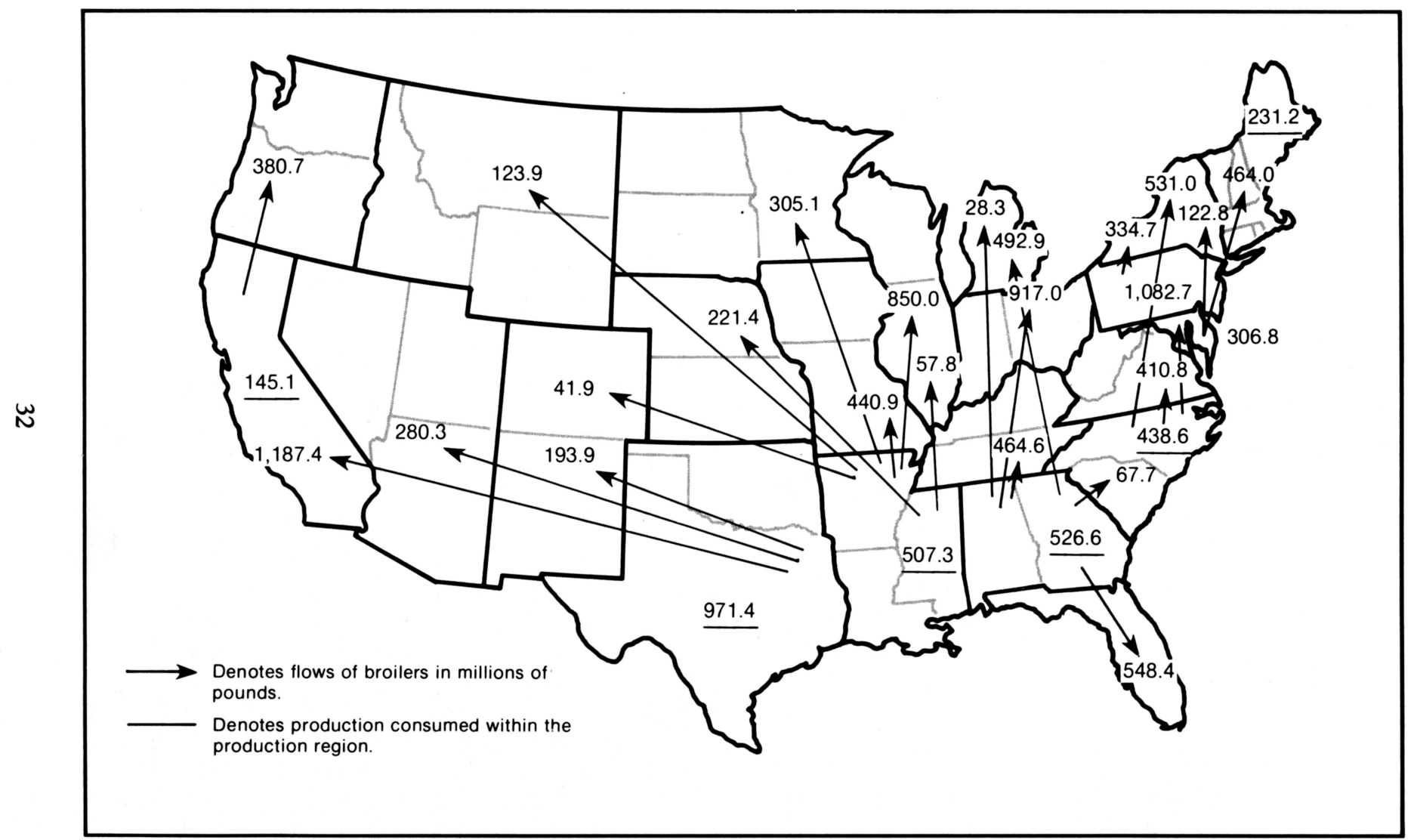

Figure 15. Least-cost Interregional Shipments for Manipulation VII. 
Table 13

Shadow Prices on Consumption by Region for the Basic Model and

Seven Manipulations

\begin{tabular}{|c|c|c|c|c|c|c|c|c|}
\hline $\begin{array}{l}\text { Consumption } \\
\text { Regions }\end{array}$ & $\begin{array}{c}\text { Basic } \\
\text { Model }\end{array}$ & $\begin{array}{l}\text { Manip- } \\
\text { ulation } \\
\text { I }\end{array}$ & $\begin{array}{l}\text { Manip- } \\
\text { ulation } \\
\text { II }\end{array}$ & $\begin{array}{l}\text { Manip- } \\
\text { ulation } \\
\text { III }\end{array}$ & $\begin{array}{l}\text { Manip- } \\
\text { ulation } \\
\text { V \& VI }\end{array}$ & $\begin{array}{l}\text { Manip- } \\
\text { ulation } \\
\text { VII }\end{array}$ & $\begin{array}{l}\text { Consumption } \\
\text { Regions }\end{array}$ & $\begin{array}{l}\text { Manip- } \\
\text { ulation } \\
\text { IV }\end{array}$ \\
\hline New England & -21.4 & $\$ 540.3$ & $\$ 558.0$ & $\$ 557.0$ & $\$ 562.7$ & $\$ 562.7$ & Mass.-Conn.-N.H.-R.I.-Vt. & $\$ 569.4$ \\
\hline N.Y. & -23.5 & 538.2 & 555.6 & 554.9 & 560.6 & 560.6 & N.Y. & 567.3 \\
\hline Pa.-N.J. & -25.6 & 536.1 & 553.3 & 552.8 & 558.5 & 558.5 & Pa.-N.J.-D.C. & 565.2 \\
\hline Md.-Del.-D.C. & -27.5 & 535.6 & 551.2 & 550.9 & 556.6 & 556.6 & S.C. & 555.0 \\
\hline Va.-W.Va. & -30.5 & 537.3 & 547.9 & 547.9 & 553.6 & 553.6 & Fla. & 560.0 \\
\hline N.C.-S.C. & -30.2 & 537.6 & 548.2 & 548.2 & 553.9 & 553.9 & Oh.-W.Va. & 562.5 \\
\hline Ga.-Ala. & -38.8 & 532.2 & 538.7 & 539.6 & 545.7 & 545.3 & Mich. & 565.5 \\
\hline Fla. & -25.8 & 545.2 & 553.0 & 552.6 & 558.7 & 558.3 & Ill.-Ind.-Wis. & 565.0 \\
\hline Mich. & -20.3 & 546.0 & 559.1 & 558.1 & 564.2 & 563.8 & Tenn.-Ky. & 555.5 \\
\hline Ohio-Ind. & -23.5 & 544.3 & 555.6 & 554.9 & 560.6 & 560.2 & Minn.-S.D.-N.D. & 570.1 \\
\hline Tenn.-Ky. & -31.4 & 540.8 & 547.0 & 547.0 & 552.7 & 552.3 & Mo.-Kan.-Neb.-Iowa & 562.0 \\
\hline Ill.-Wis. & -21.9 & 550.2 & 557.4 & 556.5 & 562.2 & 560.9 & Tex.-Okla. & 559.7 \\
\hline Miss.-La.-Ark. & -40.6 & 538.0 & 536.8 & 537.8 & 543.5 & 542.2 & Mont.-N.D.-Wyo. & 59.7 \\
\hline Minn.-S.D.-N.D. & -17.5 & 553.8 & 562.2 & 560.9 & 565.6 & 564.3 & Colo.-N.M.-Utah-Ariz. & 572.4 \\
\hline Mo.-Iowa & -29.8 & 547.8 & 548.7 & 548.3 & 553.3 & 552.0 & Wash.-Ore. & 599.0 \\
\hline Kan.-Neb. & -25.5 & 552.9 & 554.5 & 552.9 & 558.6 & 557.3 & Calif.-Nev. & 587.6 \\
\hline Tex.-Okla. & -27.9 & 547.0 & 547.0 & 547.0 & 547.0 & 547.0 & & \\
\hline Mont.-Id.-Wyo. & -5.3 & 572.5 & 575.7 & 573.1 & 557.8 & 576.5 & & \\
\hline Colo.-N.M. & -15.2 & 563.9 & 564.8 & 563.2 & 566.6 & 566.6 & & \\
\hline Ariz.-Utah-Nev. & -7.3 & 571.1 & 573.5 & 571.1 & 571.1 & 571.1 & & \\
\hline Ore.-Wash. & $-^{\star}$ & 589.5 & 592.7 & 588.6 & 590.0 & 590.0 & & \\
\hline Calif. & - $^{\star}$ & 578.6 & 581.5 & 578.4 & 579.0 & 579.0 & & \\
\hline
\end{tabular}

*Consumption is not fulfilled, therefore no shadow price is determined. 
annual per capita consumption of other meats (beef, pork, and turkeys) also increased, these were at lower rates. There remains a question of how much potential exists for additional increases in total per capita consumption of these products in the future. Undoubtedly, there are limits on the total amount of animal products each consumer needs or will buy. Therefore, the 1990 projected per capita broiler consumption used in Manipulations V, VI, and VII may be overestimated. It is likely that future increases in per capita demand for broilers will be slow relative to past industry experience. A modern, professional management approach must be used to meet the changing conditions and new challenges occurring in this very complex and dynamic industry.

\section{Conclusions}

Poultry consumption over the past two decades has increased relative to the consumption of pork and beef, the products that consumers are more likely to consider as substitutes for poultry. The broiler share of total meat (beef, pork, turkeys, and broilers) consumption rose from 14.8 percent in 1960 to 22.8 percent in 1980 (Table 14). If the ratios of retail broiler prices to retail beef and pork prices are examined, one notices a consistent regular drop in the ratios between 1965 and 1980. Retail broiler price as a percentage of beef and pork prices decreased from 47.6 percent in 1965 to 30.3 percent in 1980 for choice beef and from 59.9 percent in 1965 to 51.6 percent in 1980 for pork. This decrease in relative prices of broilers to beef and pork is a partial explanation of the gains that broilers have made in the consumption patterns of individuals in the United States. Figure 16 shows the price-quantity relationships for broilers for the period 1950-80. The data seem to line up around one smooth line. ${ }^{9}$ There has been a fairly steady drop in relative price throughout the period and a corresponding steady growth in consumption. But apparently this was a movement along the same demand curve, not a shift in the level of the curve. This could be interpreted to mean that consumers were not willing to buy more of the broiler meat at the same price, or they were not willing to buy the same quantity at a higher price during that period. Therefore, it is the development and adoption of new cost-cutting technologies which have enabled broiler producers to increase production and fulfill consumers' demands at relatively lower prices. However, since 1970 the demand for broilers in the United States seems to have become more price inelastic, so it follows that future increases in per capita broiler consumption, through price decreases, will come at a slower pace than those witnessed during the past three decades.

The impact of change in population and demand induced growth on the broiler industry was examined in Manipulations V, VI, and VII. The regional

${ }^{9}$ The data for 1973 deviates because price controls were in effect much of that year. 
Table 14

Percentage of Broiler Consumption in Relation to Total Meat Consumption, 1960-80

\begin{tabular}{|c|c|c|c|c|c|}
\hline \multirow[b]{2}{*}{ Year } & \multicolumn{4}{|c|}{$\begin{array}{c}\text { Civilian Per Capita Consumption } \\
\text { Retail Weight }\end{array}$} & \multirow{2}{*}{$\begin{array}{l}\text { Broilers as Share of } \\
\text { Total Meat Consumption }\end{array}$} \\
\hline & Beef & Pork & Turkeys & Broilers & \\
\hline & \multicolumn{4}{|c|}{ (pounds) } & (percentage $)$ \\
\hline 1960 & 63.0 & 65.3 & 6.1 & 23.4 & 14.8 \\
\hline 1961 & 65.0 & 62.8 & 7.4 & 25.9 & 16.1 \\
\hline 1962 & 65.8 & 63.6 & 7.0 & 25.8 & 15.9 \\
\hline 1963 & 69.9 & 68.7 & 6.8 & 27.1 & 15.7 \\
\hline 1964 & 73.9 & 68.6 & 7.3 & 27.7 & 15.6 \\
\hline 1965 & 73.7 & 60.5 & 7.4 & 29.6 & 17.3 \\
\hline 1966 & 77.2 & 59.2 & 7.8 & 32.0 & 18.2 \\
\hline 1967 & 78.9 & 64.9 & 8.6 & 32.4 & 17.5 \\
\hline 1968 & 81.3 & 66.1 & 7.9 & 32.8 & 17.4 \\
\hline 1969 & 82.1 & 64.3 & 8.3 & 34.8 & 18.4 \\
\hline 1970 & 84.2 & 65.5 & 8.0 & 36.8 & 18.9 \\
\hline 1971 & 83.7 & 71.2 & 8.3 & 36.5 & 18.3 \\
\hline 1972 & 85.9 & 62.9 & 8.9 & 38.2 & 19.5 \\
\hline 1973 & 81.1 & 57.6 & 8.5 & 37.2 & 20.2 \\
\hline 1974 & 86.4 & 62.2 & 8.8 & 37.2 & 19.1 \\
\hline 1975 & 88.9 & 51.2 & 8.5 & 36.7 & 19.8 \\
\hline 1976 & 95.7 & 54.6 & 9.1 & 39.9 & 20.0 \\
\hline 1977 & 93.2 & 56.7 & 9.1 & 41.1 & 20.5 \\
\hline 1978 & 88.8 & 56.9 & 9.2 & 43.8 & 22.0 \\
\hline 1979 & 79.6 & 65.2 & 9.9 & 47.7 & 23.6 \\
\hline 1980 & 78.1 & 70.2 & 10.5 & 46.9 & 22.8 \\
\hline
\end{tabular}

population of 1990 was projected assuming a uniform rate for each state. However, the 1980 population census data shows that the patterns of population change were not the uniform for each state during the 1970s. All states except New York and Rhode Island gained population during the period, with the fastest growing areas being in the Sunbelt. Figure 17 shows the percentage change of population of states between the 1970 and 1980 census. Those states which have a smaller population growth rate than the total U.S. average growth rate (11.4 percent) are mostly located in the North Central and the Northeast. It appears, then, that the effect of the uniform population growth rate approach may overstate or understate some derived regional demand for broilers in this study. 


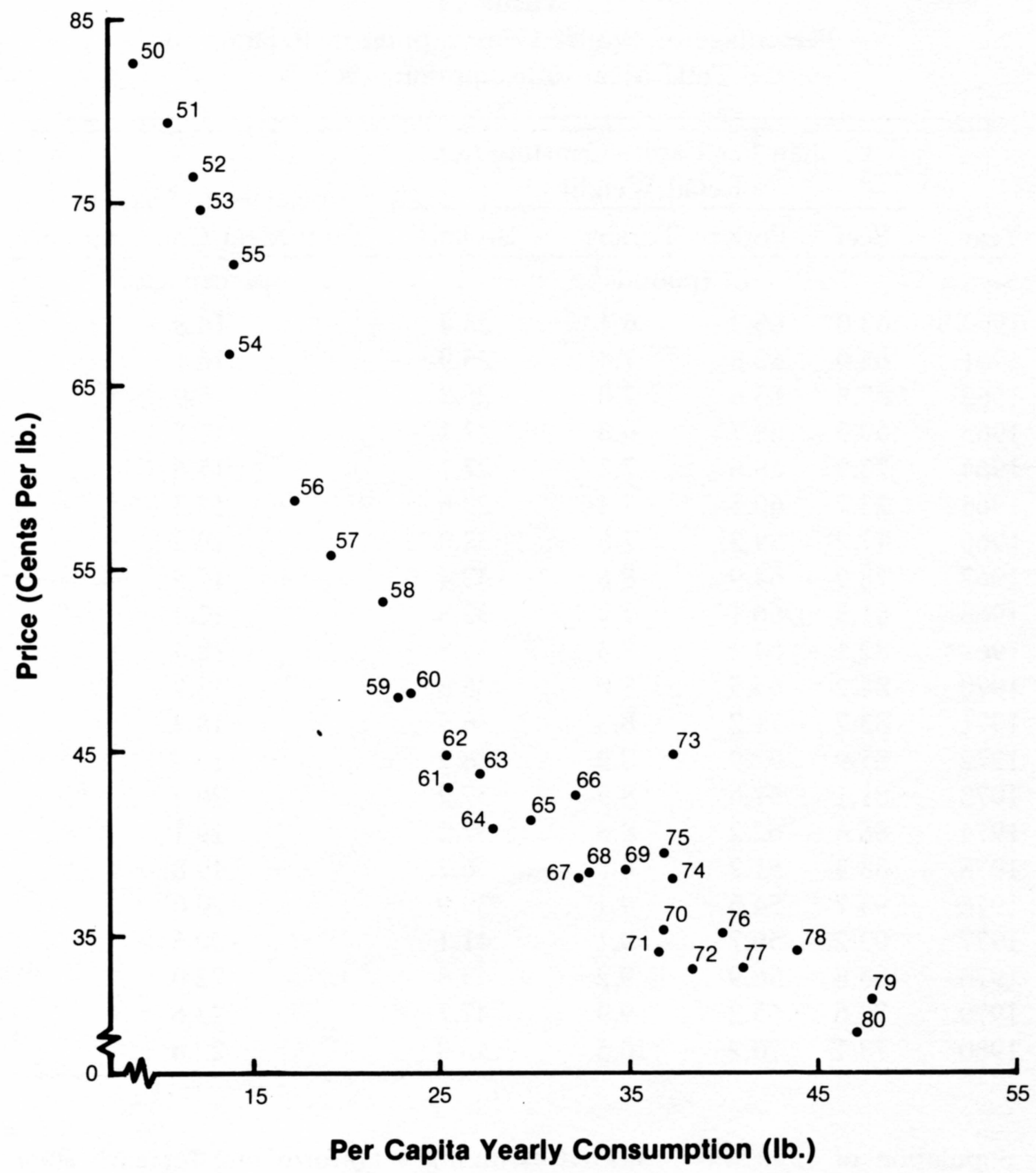

Figure 16. Annual Price` and Quantity Relationships for Broilers at Retail Level, 1950-80. 


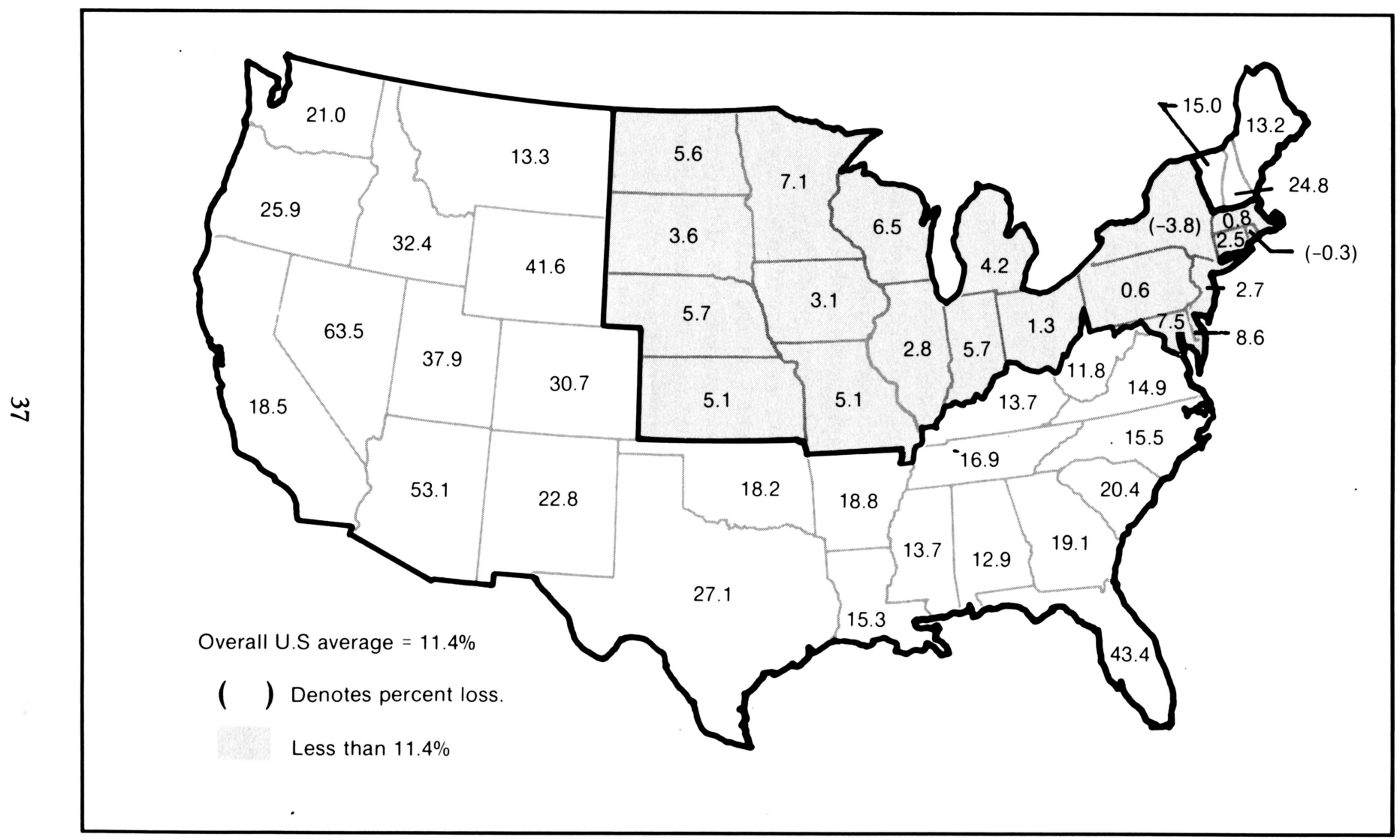

Figure 17. Percentage Change U.S. Population by States, 1970-80. 


\section{Summary}

Since the 1930s, the broiler industry in the United States has gradually shifted from an industry of specialized functions to a highly integrated industry. The tremendous changes associated with new technologies and better economic structure have brought a new set of interregional relationships within the broiler industry, which require continuous study.

Twenty-two consumption regions and ten production regions were defined in this analysis. Quantity supplied, adjusted aggregate regional consumption, production costs, and transportation rates were used to construct the Basic Model. This model was solved by using a computer routine to determine the distribution patterns that would minimize total production and shipping costs. Thereafter, seven manipulations were developed to quantitatively estimate the industry reaction to various changes which could occur.

The solution to the Basic Model showed the least-cost regional allocation of broiler production for 1980 . The basic direction of broiler movements was from south to north. The model results coincided closely with our present knowledge of the allocative pattern of the U.S. broiler industry.

The advantage of an early and rapid growth, plus the proximity to major consumer markets, of Delmarva broiler producers was examined in Manipulation I. To do this, Delmarva was allowed to increase production to satisfy nearby consumer markets which in the past have been lost to the Southern region. The resultant flow pattern was quite different from the Basic Model. The increased aggregate costs ${ }^{\star}$ over the Basic Model meant that the broiler producers in the Delmarva broiler industry would have to explore all possibilities for reducing the cost of production and improving processing performance in order to meet competition within present market outlets.

The industry's sensitivity to changes in transportation rates and production costs were examined in Manipulations II and III, respectively. The argument that production cost is more influential than transportation costs in affecting interregional competition in the broiler industry was demonstrated to be true.

The concept of the surplus or deficit status of regions was used to permit equal access to available supplies in Manipulation IV. The solution showed total net movements occurring between consumption regions. Since the leastcost flow pattern for Manipulation IV was similar to the actual flow pattern in the industry, it was concluded that under current conditions the broiler industry has achieved maximum efficiency in marketing.

In Manipulations V, VI, and VII, regional consumption of broilers was projected to 1990 with different regression equations. The competitive analyses undertaken indicated that Texas and North Carolina are in a relatively

\footnotetext{
*Costs associated with total production in the U.S. and shipping this production to points of consumption.
} 
advantageous position to expand production levels to fulfill consumption increase needed to satisfy the estimated population growth in 1990.

Three alternatives were developed to make comparison with Manipulations V, VI, VII, respectively. The solutions indicated that increased production in Texas and North Carolina, with production in other regions held constant, will be much more beneficial than increased production in equal proportion in all the production regions.

The shadow prices $\dagger$ on limited production capacity showed that aggregate cost in the industry was reduced by the largest amount when California produced one additional unit of broilers. This implies that California has the economic potential to become more important in the broiler industry. This was not unexpected since California is the only broiler producer on the West Coast and the region is a deficit production area. The shadow price for the 22 consumption regions were similar for all manipulations with the highest shadow price for the Oregon-Washington region, which was located relatively far from current major broiler production regions.

†The shadow price is defined as the reduction in aggregate cost accompanying the employment of an additional unit of resource in production. 
[Blank Page in Original Bulletin] 
[Blank Page in Original Bulletin] 


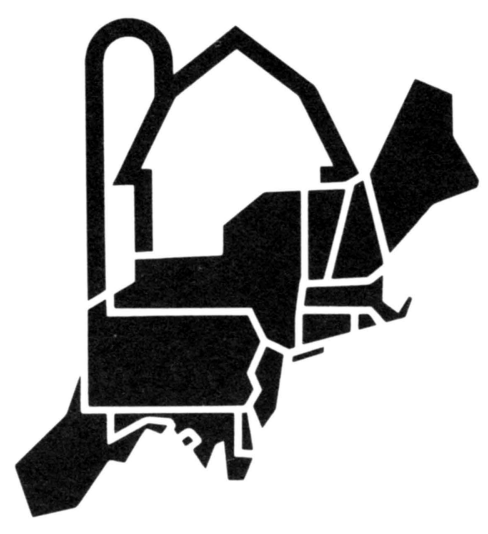

Northeast Regional Research Publication 